Prepared in cooperation with the City of North Port and Sarasota County

\title{
Discharge, Water Temperature, and Water Quality of Warm Mineral Springs, Sarasota County, Florida: A Retrospective Analysis
}

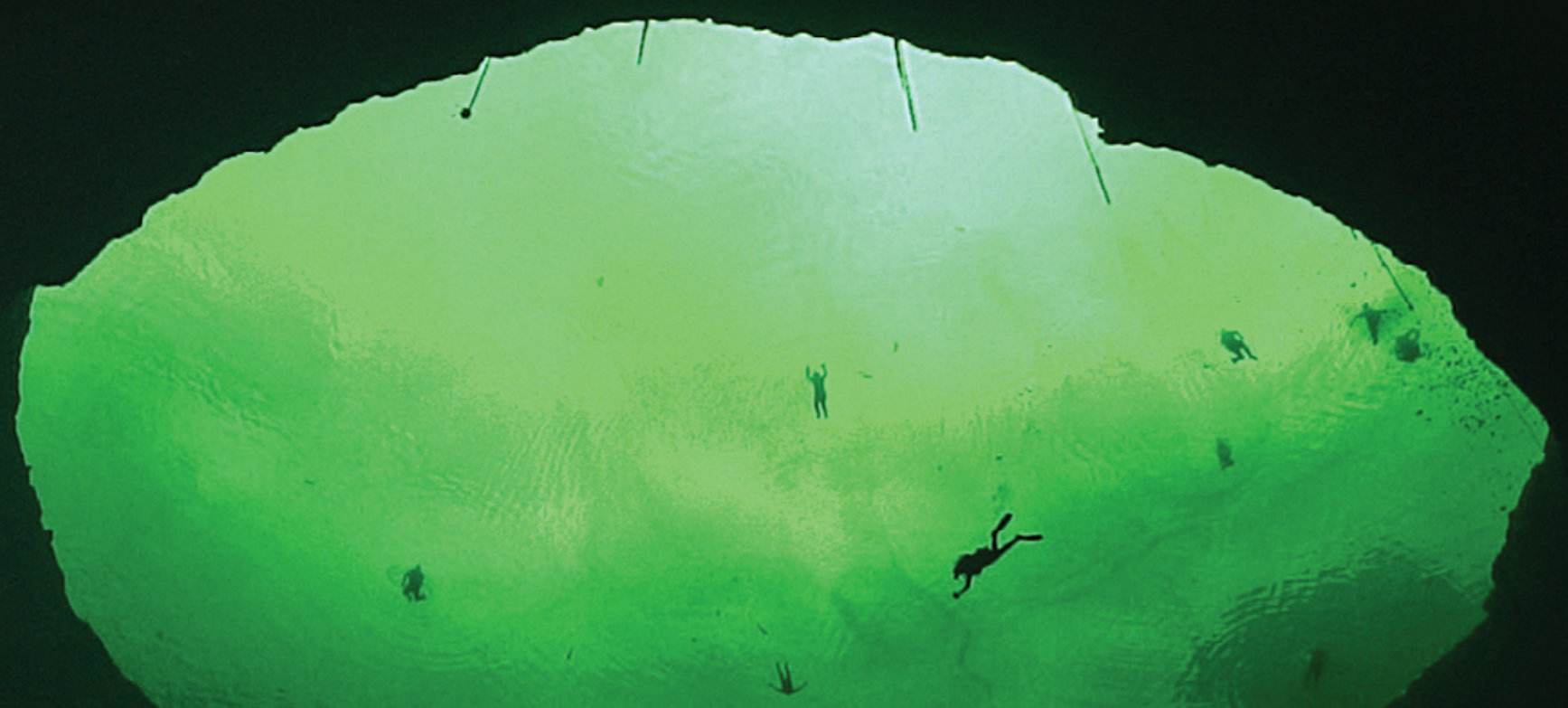

Open-File Report 2016-1166 
Cover. Photograph of Warm Mineral Springs taken by diver at 154 feet below the spring surface, July 29, 2015. Photograph by Curt Bowen, ADM Exploration Foundation, 2015.

Title page. Photograph of warm water vapors rising from the surface of Warm Mineral Springs on a cool winter morning, January 29, 2015. Photograph by P.A. Metz. 


\section{Discharge, Water Temperature, and Water Quality of Warm Mineral Springs, Sarasota County, Florida: A Retrospective Analysis}

By Patricia A. Metz

Prepared in cooperation with the City of North Port and Sarasota County

Open-File Report 2016-1166

U.S. Department of the Interior

U.S. Geological Survey 


\title{
U.S. Department of the Interior SALLY JEWELL, Secretary
}

\section{U.S. Geological Survey Suzette M. Kimball, Director}

\author{
U.S. Geological Survey, Reston, Virginia: 2016
}

For more information on the USGS - the Federal source for science about the Earth, its natural and living resources, natural hazards, and the environment-visit http://www.usgs.gov or call 1-888-ASK-USGS.

For an overview of USGS information products, including maps, imagery, and publications, visit http://store.usgs.gov.

Any use of trade, firm, or product names is for descriptive purposes only and does not imply endorsement by the U.S. Government.

Although this information product, for the most part, is in the public domain, it also may contain copyrighted materials as noted in the text. Permission to reproduce copyrighted items must be secured from the copyright owner.

Suggested citation:

Metz, P.A., 2016, Discharge, water temperature, and water quality of Warm Mineral Springs, Sarasota County, Florida-A retrospective analysis: U.S. Geological Survey Open-File Report 2016-1166, 31 p., http://dx.doi.org/10.3133/ofr20161166. 


\section{Contents}

Acknowledgments ……................................................................................................................

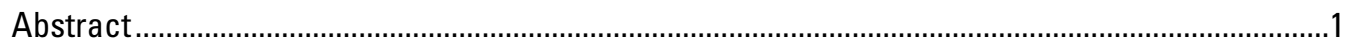

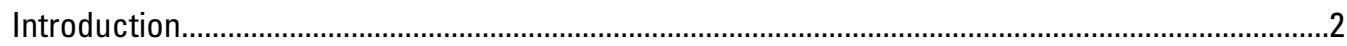

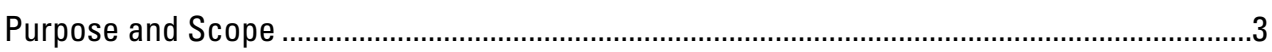

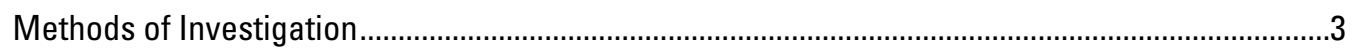

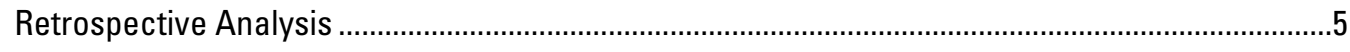

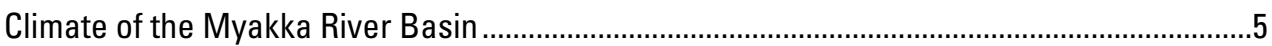

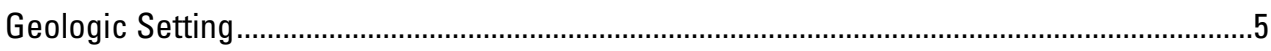

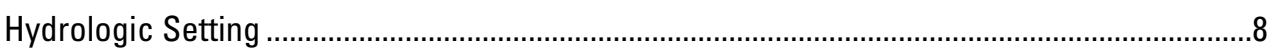

Regional Groundwater Levels and Water Use of the Upper Floridan aquifer ..................8

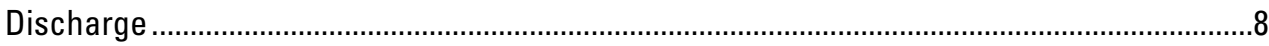

Water Level in the Sarasota 9 Well and Relation to Spring Discharge ...........................13

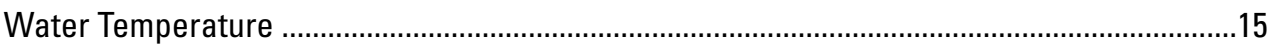

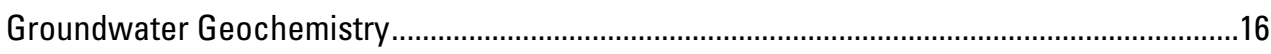

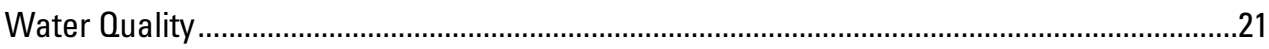

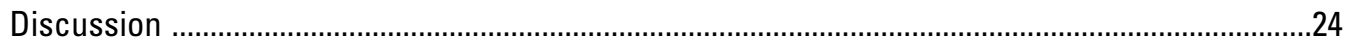

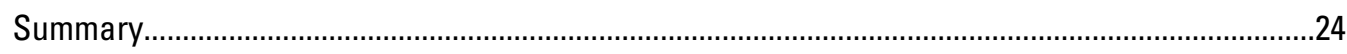

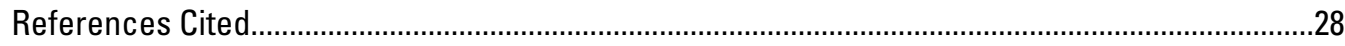

\section{Figures}

1. Maps showing location of Warm Mineral Springs, other springs in Florida, and the extent of the Florida Platform

2. Photograph showing aerial view of Warm Mineral Springs and Warm Mineral Springs Creek 3

3. Graph showing annual precipitation in the Myakka River Basin, 1940-2015............................5

4. Diagram showing relation of stratigraphic and hydrogeologic units of the Florida Platform in central Florida.

5. Map showing the geology of Warm Mineral Springs and photograph showing flowstones located on the walls of Warm Mineral Springs

6. Map showing area of recharge and discharge, potentiometric surface of the Upper Floridan aquifer for September 2010, generalized groundwater flow path in the Southern West-Central Florida Groundwater Basin, and location of wells used in this study

7. Graphs showing estimated groundwater use in the Southern West-Central Florida Groundwater Basin and estimated groundwater use in Sarasota County

8. Maps showing change in the potentiometric surface of the Upper Floridan aquifer between predevelopment levels and May 1975 levels, and change between predevelopment levels and May 2007 levels

9. Graph showing instantaneous discharge and water temperature measurements at Warm Mineral Springs 
10. Diagram of the bottom of Warm Mineral Springs showing the location of spring vents $A-E$ and photographs showing some of the spring vents

11. Graph showing time series of instantaneous discharge at Warm Mineral Springs and annual mean and monthly water-level elevation of the Upper Floridan aquifer in the Sarasota 9 well.

12. Graph showing annual mean or instantaneous discharge at Warm Mineral Springs and water-level elevation of the Upper Floridan aquifer in the Sarasota 9 well. .15

13. Graph showing time series of water temperature readings from sensors attached to divers during a sampling event on April 29, 2015

14. Cross section of hydrologic units along ROMP wells and well 224B-1, showing a pattern of increasing groundwater temperatures from Highlands to Sarasota Counties

15. Geophysical temperature logs showing the possible mixing of cooler Gulf of Mexico water with groundwater from several high permeable zones within the Floridan aquifer system

16. Stiff diagrams of water from Little Salt Spring and Warm Mineral Springs, Gulf of Mexico, and Upper Floridan aquifer and middle confining unit within the Avon Park Formation in a recharge and discharge area

17. Diagram showing comparison of water quality, temperature with depth, and flow directions within the Avon Park Formation of the Upper Floridan aquifer and the underlying middle confining unit.

18. Photographs showing sulfur-reducing bacteria and green algae that coat the walls of Warm Mineral Springs.

19. Photographs showing Warm Mineral Springs water clarity at 40 feet below the spring surface during a dry period and at 154 feet after an extended period of rain

\section{Tables}

1. Water levels above or below land surface for selected Regional Observation Monitor-Well Program wells, 2007-15.

2. Instantaneous discharge and water temperature measurements made at Warm Mineral Springs outlet and average, annual water levels for the Upper Floridan aquifer

3. Water-quality characteristics of samples collected at four vents at the bottom of Warm Mineral Springs, April 29, 2015

4. Median values of water-quality data collected at Warm Mineral Springs, Baird Creek Head Spring, and numerous west-central Florida springs and the Gulf of Mexico. 


\section{Conversion Factors}

Inch/Pound to International System of Units

\begin{tabular}{lcl}
\hline \multicolumn{1}{c}{ Multiply } & By & \multicolumn{1}{c}{ To obtain } \\
\hline inch (in.) & Length & \\
foot (ft) & 25.4 & millimeter $(\mathrm{mm})$ \\
mile (mi) & 0.3048 & meter $(\mathrm{m})$ \\
\hline & 1.609 & kilometer $(\mathrm{km})$ \\
\hline square mile $\left(\mathrm{mi}^{2}\right)$ & Area & \\
square mile $\left(\mathrm{mi}^{2}\right)$ & 259.0 & hectare $($ ha $)$ \\
\hline & 2.590 & square kilometer $\left(\mathrm{km}^{2}\right)$ \\
\hline gallon $($ gal) & Volume & \\
gallon (gal) & 3.785 & liter $(\mathrm{L})$ \\
million gallons $(\mathrm{Mgal})$ & 0.003785 & cubic meter $\left(\mathrm{m}^{3}\right)$ \\
\hline & 3,785 & cubic meter $\left(\mathrm{m}^{3}\right)$ \\
\hline cubic foot per second $(\mathrm{ft} / \mathrm{s})$ & Flow rate & \\
cubic foot per second $\left(\mathrm{ft}^{3} / \mathrm{s}\right)$ & 0.02832 & cubic meter per second $\left(\mathrm{m}^{3} / \mathrm{s}\right)$ \\
million gallons per day $(\mathrm{Mgal} / \mathrm{d})$ & 0.646 & million gallons per day $(\mathrm{Mgal} / \mathrm{d})$ \\
inch per year $($ in $/ \mathrm{yr})$ & 0.04381 & cubic meter per second $\left(\mathrm{m}^{3} / \mathrm{s}\right)$ \\
cubic meter per second $\left(\mathrm{m}^{3} / \mathrm{s}\right)$ & 25.4 & millimeter per year $(\mathrm{mm} / \mathrm{yr})$ \\
\hline
\end{tabular}

Temperature in degrees Celsius $\left({ }^{\circ} \mathrm{C}\right)$ may be converted to degrees Fahrenheit $\left({ }^{\circ} \mathrm{F}\right)$ as ${ }^{\circ} \mathrm{F}=\left(1.8 \times{ }^{\circ} \mathrm{C}\right)+32$.

Temperature in degrees Fahrenheit $\left({ }^{\circ} \mathrm{F}\right)$ may be converted to degrees Celsius $\left({ }^{\circ} \mathrm{C}\right)$ as ${ }^{\circ} \mathrm{C}=\left({ }^{\circ} \mathrm{F}-32\right) / 1.8$.

\section{Datum}

Vertical coordinate information is referenced to the National Geodetic Vertical Datum of 1929 (NGVD 29). Horizontal coordinate information is referenced to the North American Datum of 1983 (NAD 83). Elevation, as used in this report, refers to distance above the vertical datum.

\section{Supplemental Information}

Specific conductance is given in microsiemens per centimeter at 25 degrees Celsius $\left(\mu \mathrm{S} / \mathrm{cm}\right.$ at $\left.25{ }^{\circ} \mathrm{C}\right)$. Concentrations of chemical constituents in water are given in either milligrams per liter $(\mathrm{mg} / \mathrm{L})$ or micrograms per liter $(\mu \mathrm{g} / \mathrm{L})$.

\section{Abbreviations}

bls below land surface

FGS Florida Geological Survey

IRF Impulse Response Function

ka thousand years ago

$\mathrm{Ma}$ million years ago

ROMP Regional Observation and Monitor-Well Program

SWFWMD Southwest Florida Water Management District

USGS U.S. Geological Survey 


\section{Acknowledgments}

The author is grateful to the public and private sector for providing information pertaining to Warm Mineral Springs and to the City of North Port and Sarasota County for allowing access to the spring property for data-collection purposes. Acknowledgments are extended to the City of North Port employees Daniel Schult, Michele Norton, and Jim McAllister; and Sarasota County employees Cliff Harrison, Chris Cole, John Ryan, and Rachel Herman for technical discussions pertaining to Warm Mineral Springs. The author acknowledges the assistance of Sarasota County employees Cliff Harrison, Rene Janneman, Ashley Melton, Cesar Rodriguez, and Heather Bryen for their technical field support. Also, gratitude is extended to Curt Bowen of ADM Exploration Foundation and Jim Culter of Mote Marine Laboratory for assistance with collecting water samples from the vents at the bottom of the spring during 2015. Curt Bowen also provided underwater videography and detailed mapping of the spring for this study. Special recognition is given to both William Royal and William Cockrell for their archaeological research over the years at Warm Mineral Springs.

The author acknowledges Joseph D. Hughes, U.S. Geological Survey, Office of Groundwater, John F. Stamm, U.S. Geological Survey, Caribbean-Florida Water Science Center, and Dave DeWitt, Southwest Florida Water Management District, for their constructive technical reviews of the report. 


\section{Discharge, Water Temperature, and Water Quality of Warm Mineral Springs, Sarasota County, Florida: A Retrospective Analysis}

By P.A. Metz

\section{Abstract}

Warm Mineral Springs, located in southern Sarasota County, Florida, is a warm, highly mineralized, inland spring. Since 1946, a bathing spa has been in operation at the spring, attracting vacationers and health enthusiasts. During the winter months, the warm water attracts manatees to the adjoining spring run and provides vital habitat for these mammals. Wellpreserved late Pleistocene to early Holocene-age human and animal bones, artifacts, and plant remains have been found in and around the spring, and indicate the surrounding sinkhole formed more than 12,000 years ago. The spring is a multiuse resource of hydrologic importance, ecological and archeological significance, and economic value to the community.

The pool of Warm Mineral Springs has a circular shape that reflects its origin as a sinkhole. The pool measures about 240 feet in diameter at the surface and has a maximum depth of about 205 feet. The sinkhole developed in the sand, clay, and dolostone of the Arcadia Formation of the Miocene-age to Oligocene-age Hawthorn Group. Underlying the Hawthorn Group are Oligocene-age to Eocene-age limestones and dolostones, including the Suwannee Limestone, Ocala Limestone, and Avon Park Formation. Mineralized groundwater, under artesian pressure in the underlying aquifers, fills the remnant sink, and the overflow discharges into Warm Mineral Springs Creek, to Salt Creek, and subsequently into the Myakka River. Aquifers described in the vicinity of Warm Mineral Springs include the surficial aquifer system, the intermediate aquifer system within the Hawthorn Group, and the Upper Floridan aquifer in the Suwannee Limestone, Ocala Limestone, and Avon Park Formation. The Hawthorn Group acts as an upper confining unit of the Upper Floridan aquifer.

Groundwater flow paths are inferred from the configuration of the potentiometric surface of the Upper
Floridan aquifer for September 2010. Groundwater flow models indicate the downward flow of water into the Upper Floridan aquifer in inland areas, and upward flow toward the surface in coastal areas, such as at Warm Mineral Springs. Warm Mineral Springs is located in a discharge area. Changes in water use in the region have affected the potentiometric surface of the Upper Floridan aquifer. Historical increase in groundwater withdrawals resulted in a 10 - to 20 -foot regional decline in the potentiometric surface of the Upper Floridan aquifer by May 1975 relative to predevelopment levels and remained at approximately that level in May 2007 in the area of Warm Mineral Springs. Discharge measurements at Warm Mineral Springs (1942-2014) decreased from about 11-12 cubic feet per second in the 1940s to about 6-9 cubic feet per second in the 1970s and remained at about that level for the remainder of the period of record. Similarity of changes in regional water use and discharge at Warm Mineral Springs indicates that basin-scale changes to the groundwater system have affected discharge at Warm Mineral Springs. Water temperature had no significant trend in temperature over the period of record, 1943-2015, and outliers were identified in the data that might indicate inconsistencies in measurement methods or locations.

Within the regional groundwater basin, Warm Mineral Springs is influenced by deep Upper Floridan aquifer flow paths that discharge toward the coast. Associated with these flow paths, the groundwater temperatures increase with depth and toward the coast. Multiple lines of evidence indicate that a source of warm groundwater to Warm Mineral Springs is likely the permeable zone of the Avon Park Formation within the Upper Floridan aquifer at a depth of about 1,400 to 1,600 feet, or deeper sources. The permeable zone contains saline groundwater with water temperatures of at least 95 degrees Fahrenheit. 
The water quality of Warm Mineral Springs, when compared with other springs in Florida had the highest temperature and the greatest mineralized content. Warm Mineral Springs water is characterized by a slight-green color, with varying water clarity, low dissolved oxygen (indicative of deep groundwater), and a hydrogen sulfide odor. Water-quality samples detected ammonium-nitrogen and nitrates, but at low concentrations. The drinking water standard for nitrate adopted by the U.S. Environmental Protection Agency is 10 milligrams per liter, measured as nitrogen. Water samples collected at spring vents by divers on April 29, 2015, had concentrations of 0.9 milligram per liter nitrate-nitrogen at vent $\mathrm{A}$ and 0.04-0.05 milligram per liter at vents B, C, and D. Typically, the water clarity is highest in the morning (about 30 feet Secchi depth) and often decreases throughout the day.

Analysis of existing data provided some insight into the hydrologic processes affecting Warm Mineral Springs; however, data have been sparsely and discontinuously collected since the 1940s. Continuous monitoring of hydrologic characteristics such as discharge, water temperature, specific conductance, and water-quality indicators, such as nitrate and turbidity (water clarity), would be valuable for monitoring and development of models of spring discharge and water quality. In addition, water samples could be analyzed for isotopic tracers, such as strontium, and the results used to identify and quantify the sources of groundwater that discharge at Warm Mineral Springs. Groundwater flow/transport models could be used to evaluate the sensitivity of the quality and quantity of water flowing from Warm Mineral Springs to changes in climate, aquifer levels, and water use.

\section{Introduction}

Warm Mineral Springs, in southern Sarasota County, Florida, (fig. 1A), is a warm (about 85 degrees Fahrenheit $\left[{ }^{\circ} \mathrm{F}\right]$ ), mineralized spring (Rosenau and others, 1977). Since 1946, a bathing spa has been in operation at the spring, attracting vacationers and health enthusiasts (Scott and others, 2004). Archaeological evidence indicates that the spring has been visited by humans for thousands of years; well-preserved Pleistocene- to early Holocene-age human and animal bones, artifacts, and plant remains have been found in and around the spring (Clausen and others, 1975; Cockrell, 1975). In addition, the warm water from the spring attracts manatees to the adjoining spring run during the winter months and provides vital habitat. Warm Mineral Springs is a multiuse resource, with several stakeholders expressing interest in its development, management, and sustainable use.

Warm Mineral Springs is a third-magnitude spring, which is defined as having discharge less than 10 cubic feet per second ( $\mathrm{ft}^{3} / \mathrm{s}$; Copeland, 2003). The spring pool measures about 240 feet ( $\mathrm{ft}$ ) in diameter at the surface (Clausen and others, 1975) and has a maximum depth of about $205 \mathrm{ft}$ (Bowen, 1996). The circular shape (fig. 2) and depth of the pool reflects
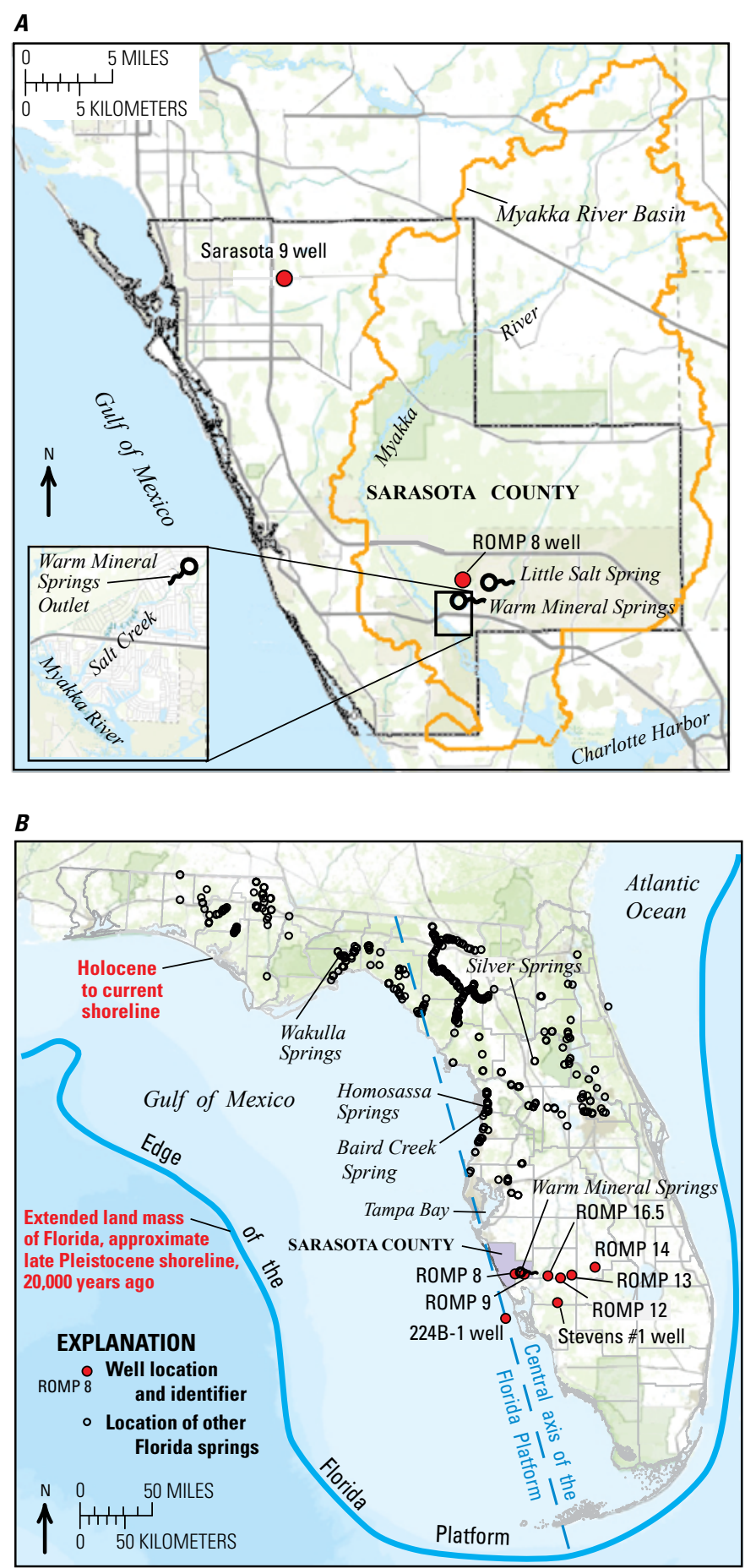

Base modified from Esri, DeLorme, HERE, TomTom, Intermap, increment P Corp., GEBCO, USGS, FAO, NPS, NRCAN, GeoBase, IGN, Kadaster NL, Ordnance Survey, Esri Japan, METI, Esri China (Hong Kong), swisstopo, and the GIS User Community

Figure 1. Location of $A$, Warm Mineral Springs and $B$, other springs in Florida and the extent of the Florida Platform.

its origin as a sinkhole that developed in the underlying carbonate rocks. Caverns, or "vents," along the sinkhole bottom discharge warm water to the spring (Rupert, 1994; Bowen, 2015). 


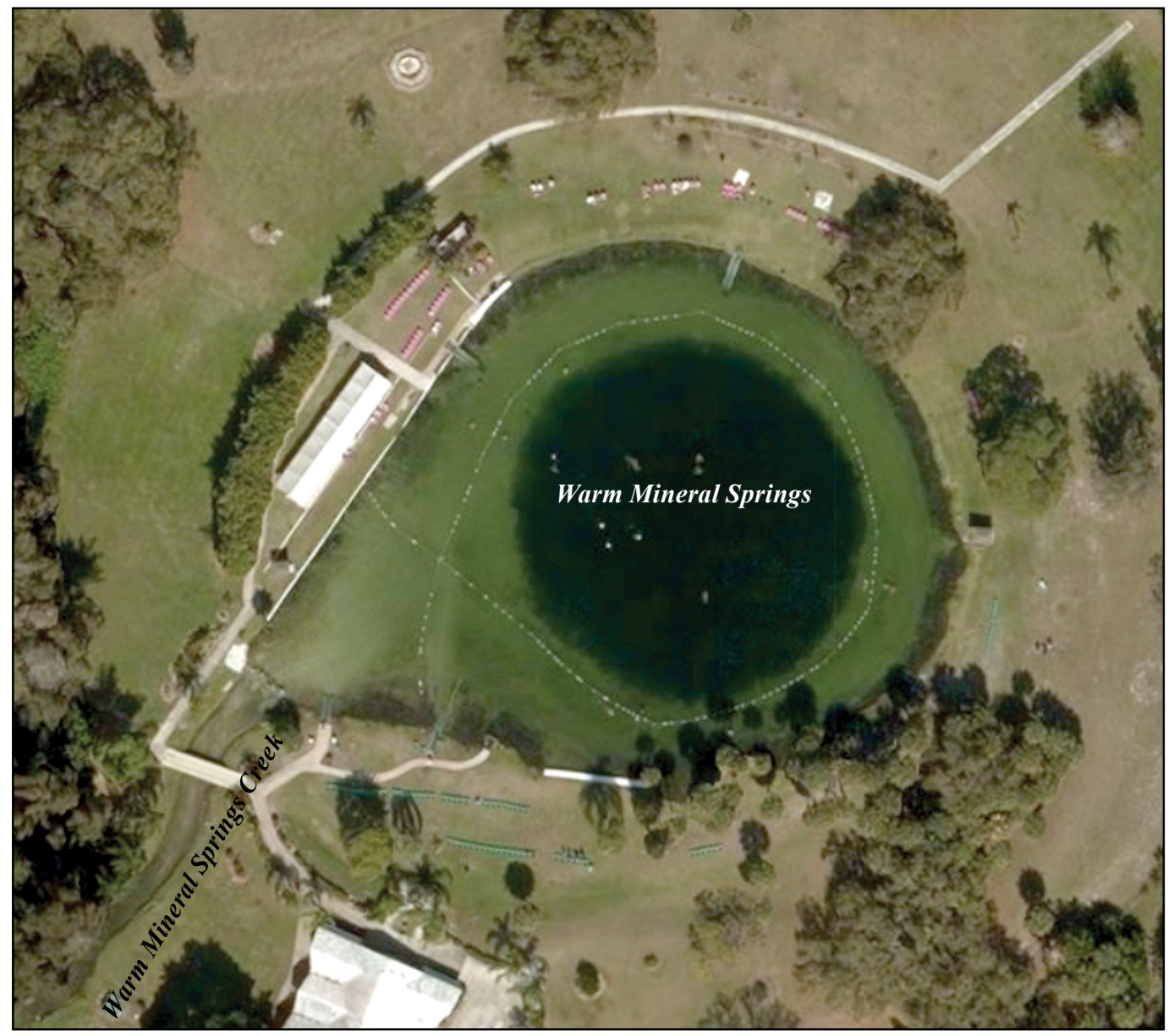

Base modified from Esri, DigitalGlobe, GeoEye, i-cubed,

USDA, USGS, AEX, Getmapping, Aerogrid, IGN,

IGP, swisstopo, and the GIS User Community

Figure 2. Aerial view of Warm Mineral Springs and Warm Mineral Springs Creek.

\section{Purpose and Scope}

The purpose and scope of this report is to provide a summary of retrospective studies (available from published reports and databases) pertaining to the geologic and hydrologic setting of the region, and the water temperature, discharge, and water chemistry of Warm Mineral Springs. The study area includes Warm Mineral Springs and the Myakka River Basin (fig. 1A). Data were compiled from published sources from various agencies including the Florida Geological Survey, Sarasota County, Southwest Florida Water Management District (SWFWMD), and the U.S. Geological Survey (USGS). Data from the SWFWMD Regional Observation Monitor-Well Program (ROMP), and other wells, were used to assess regional groundwater levels.

The USGS in cooperation with the City of North Port and Sarasota County, Florida, conducted a study to review, summarize, and analyze existing data pertaining to Warm Mineral Springs. The retrospective summary addresses (1) the regional hydrologic and geologic setting, (2) anthropogenic effects such as water use, (3) sources of warm water, (4) discharge and water temperature, and (5) geochemistry and water quality. The associated analyses are intended to provide information to local, regional, and State water-resource professionals to better understand and sustainably manage Warm Mineral Springs.

\section{Methods of Investigation}

The results presented in this report are based on published reports and data pertaining to Warm Mineral Springs and the surrounding region. Warm Mineral Springs has a long history of scientific research pertaining to archaeology and paleoecology, geology, hydrology, and water temperature/quality within and surrounding the spring. Hereinafter, "water temperature" will be referred to as "temperature" unless otherwise noted. Some notable studies of Warm Mineral Springs and other related investigations include the following: archaeological 
and paleoecology investigations (Royal and Clark, 1960; Clausen and others, 1975; Cockrell, 1988; McDonald,1990), regional geologic framework (Miller, 1986; Reese and Richardson, 2008; Williams and Kuniansky, 2015), local geologic framework (Hutchinson, 1992; Thompson, 1997; Baldini, 1998; Clayton, 1998, 1999, 2010; Gates, 2001), geologic setting of Warm Mineral Springs (Rupert, 1994), mapping of the spring configuration and videography of caves (Bowen, 1996, 2015), regional hydrology (Kohout, 1965; Stringfield, 1966; Vernon, 1970; Henry and Kohout, 1972; Kohout and others, 1977; Johnston and others, 1980; Ryder, 1985; Metz and Lewelling, 2009), groundwater temperature (Darton, 1920; Kohout, 1967; Griffin and others, 1969; Clausen and others, 1975; Griffin and others, 1977; Kohout and others, 1977; Sproul, 1977; Sacks and Tihansky, 1996), water quality (Rosenau and others, 1977; Hutchinson, 1992; Sacks and Tihansky, 1996; Scott and others, 2004; and Ryan and others, 2011), modeling of groundwater levels, temperature, and chloride (Hughes and others, 2007, 2009), and analysis of collapsed geologic features or structural anomalies and their relation to the movement of groundwater (Popenoe and others, 1984; Hutchinson, 1992; Spechler, 1994, 1996; Spechler and Wilson, 1997; Odum and others, 1999; Cunningham, 2013).

Regional analyses were based in part on analyses of groundwater levels in wells. Hereinafter, the term "water level" will be used for the elevation of the groundwater in a well open to an unconfined aquifer and for the elevation to which groundwater would potentially rise in a well that penetrated a confined aquifer. If the water level rises above the confining layer that overlies the aquifer or if groundwater flows to the surface, the well is considered an artesian well (Fetter, 2001; Perlman, 2016). In confined aquifers, groundwater levels could potentially rise to elevations above the land surface. Water levels and temperatures were analyzed from six ROMP wells (ROMP 8, 9, 12, 13, 14, 16.5), the Stevens \#1 well (Kohout and others, 1977), Sarasota 9 well, and a deep exploratory Gulf of Mexico well (State of Florida Lease 224-B, well \#1; USGS well 264107082190301; Kohout and others, 1977; fig. 1). When necessary, water levels in wells were corrected for salinity based on methods by Guo and Langevin (2002). Salinity corrections were applied to aquifer water levels from the ROMP 8, 9, 12, and 16.5 wells. Data for ROMP wells and the Sarasota 9 well were obtained from the Southwest Florida Water Management Information System (Southwest Florida Water Management District, 2016a).

Potential areas of groundwater recharge and discharge were identified by comparing the elevation of the potentiometric surface of the Upper Floridan aquifer for September 2010 (Ortiz, 2011) and land-surface elevation data (U.S. Geological Survey EROS Data Center, 1999). The potentiometric surface represents the level to which groundwater would rise in a cased well (Fetter, 2001). A potentiometric surface is constructed by interpolating the water levels in wells over an area of interest at a given time. Four wells in Sarasota County used to compute the September 2010 potentiometric surface were corrected for salinity (Ortiz, 2011). Areas where the potentiometric surface was below the land surface were considered potential areas of groundwater recharge, and areas where the potentiometric surface was above the land surface were considered potential areas of groundwater discharge. Potentiometric surfaces for predevelopment levels (Johnston and others, 1980) were compared with May 1975 levels (Mills and Laughlin, 1976) and May 2007 levels (Ortiz, 2008), as reported by Metz and Lewelling (2009). Three wells in Sarasota County were corrected for salinity on the May 2007 potentiometric surface (Ortiz, 2008).

Climate data for the Myakka River watershed were obtained from the Southwest Florida Water Management Information System (Southwest Florida Water Management District, 2016b). Discharge data at the spring outlet were obtained from various sources, including Rosenau and others (1977), Scott and others (2004), USGS site numbers 02299260 and 270333082154000 (National Water Information System [NWIS]; http://nwis.waterdata.usgs.gov/fl/nwis/nwis), Southwest Florida Water Management Information System (Southwest Florida Water Management District, 2016a), and from Hydrologic Data Collection, Inc. (http://www.hydrologicdata. com). Water-use data for counties in Florida for the period 1965-2010 were obtained from the U.S. Geological Survey (2016), and from Metz and Lewelling (2009).

Groundwater geochemistry of Warm Mineral Springs, and wells and springs in the region were obtained from archives by the USGS NWIS, and the Southwest Florida Water Management Information System (Southwest Florida Water Management District, 2016a). Geochemical and waterquality data are also compiled in reports by Rosenau and others (1977), Scott and others (2004), Harrington and others, (2010), Ryan and others (2011), and databases of Sarasota County (2016a), Southwest Florida Water Management District (2016a), and the USGS NWIS (USGS site numbers 02299260 and 270333082154000 ). Water samples collected on January 31, 1985, at Warm Mineral Springs (USGS site number 02299260) were analyzed for anthropogenic compounds; however, no compounds were detected above the minimum reporting level, and this analysis will not be discussed in this report.

The City of North Port contracted divers to collect water samples and temperature data from Warm Mineral Springs on April 29, 2015. Samples were collected at four vents at the spring bottom and were analyzed to assess nutrients and major chemical constituents. During this sampling event continuous water temperature sensors that collected data at 1-second intervals were attached to two divers on a descent to the bottom spring vents. Data were stored in the Sarasota County Water Atlas (Sarasota County, 2016b, 2016c).

Statistical analyses were computed using the R statistical package (R Core Team, 2012). Statistical significance of trends were based on the Kendall's tau non-parametric test (Helsel, and Hirsch, 2002). Significance was based on a 0.05 probability of a type I error (probability of rejecting the null hypothesis when true). 


\section{Retrospective Analysis}

The retrospective analysis of Warm Mineral Springs includes a summary of the climate, geologic setting, and hydrologic setting at a statewide to local scale. This description is followed by a discussion of the local geologic and hydrologic characteristics of Warm Mineral Springs, including the discharge, water temperature, geochemistry, and water quality of the spring.

\section{Climate of the Myakka River Basin}

Warm, wet summers and relatively mild, dry springs characterize the subtropical climate of Myakka River Basin, where Warm Mineral Springs is located (fig. 1A). Rainfall varies seasonally, and more than half of the annual rainfall typically occurs during the summer months (June through September; Basso and Schultz, 2003). Rainfall can be unevenly distributed throughout Sarasota County during the summer rainy season because the rain is derived from localized, convective thunderstorms. Winter rainfall is more evenly distributed because storms generally come from frontal air masses that move from north to south across the State (Metz and Lewelling, 2009). The median annual rainfall for 1940-2015 for the Myakka River Basin was 53 inches per year (in/yr; fig. 3). There was no significant trend in annual precipitation for water years 1940-2015, based on the Kendall's tau nonparametric test.

\section{Geologic Setting}

Warm Mineral Springs is located near the central axis of the Florida Platform (fig. 1B). The Florida Platform throughout its history has been flooded by the sea or exposed as dry land (Randazzo, 1997; Hine, 2013). Warm Mineral Springs is located on the Pleistocene-age (2.6-0.01 million years ago [Ma]) Palmico terrace (Healy, 1975), which formed when sea level rose to an elevation of about 25 to $30 \mathrm{ft}$ (MacNeil, 1949); the land surface at Warm Mineral Springs is at an elevation of about $10 \mathrm{ft} \mathrm{NGVD} 29$ (at USGS site number 270333082154000). The dominant bedrock of the Florida Platform consists of carbonate rocks, such as limestone and dolostone, that span the Cenozoic Era (66-0 Ma; Hine, 2013; fig. 4). The geologic formations exposed at Warm Mineral Springs consist of the late Oligocene-age (the Oligocene Epoch spans 34-23 Ma) to Miocene-age (23-5 Ma) Arcadia Formation of the Hawthorn Group (fig. 5A). The Hawthorn Group is composed of carbonate rocks with sand and clay layers (Clayton, 2010). The Arcadia Formation includes dolostone, phosphatic sand, and dolomitic clay (Rupert, 1994). Underlying the Hawthorn Group are Oligocene-age to Eocene-age (56-34 Ma) limestones and dolostones, including the Suwannee Limestone, Ocala Limestone, and Avon Park Formation (fig. 4).

The carbonate rocks surrounding and underlying Warm Mineral Springs were deposited in both open and restricted marine environments. Later erosion and weathering of these carbonate rocks resulted in the vugs, cavities, and solution

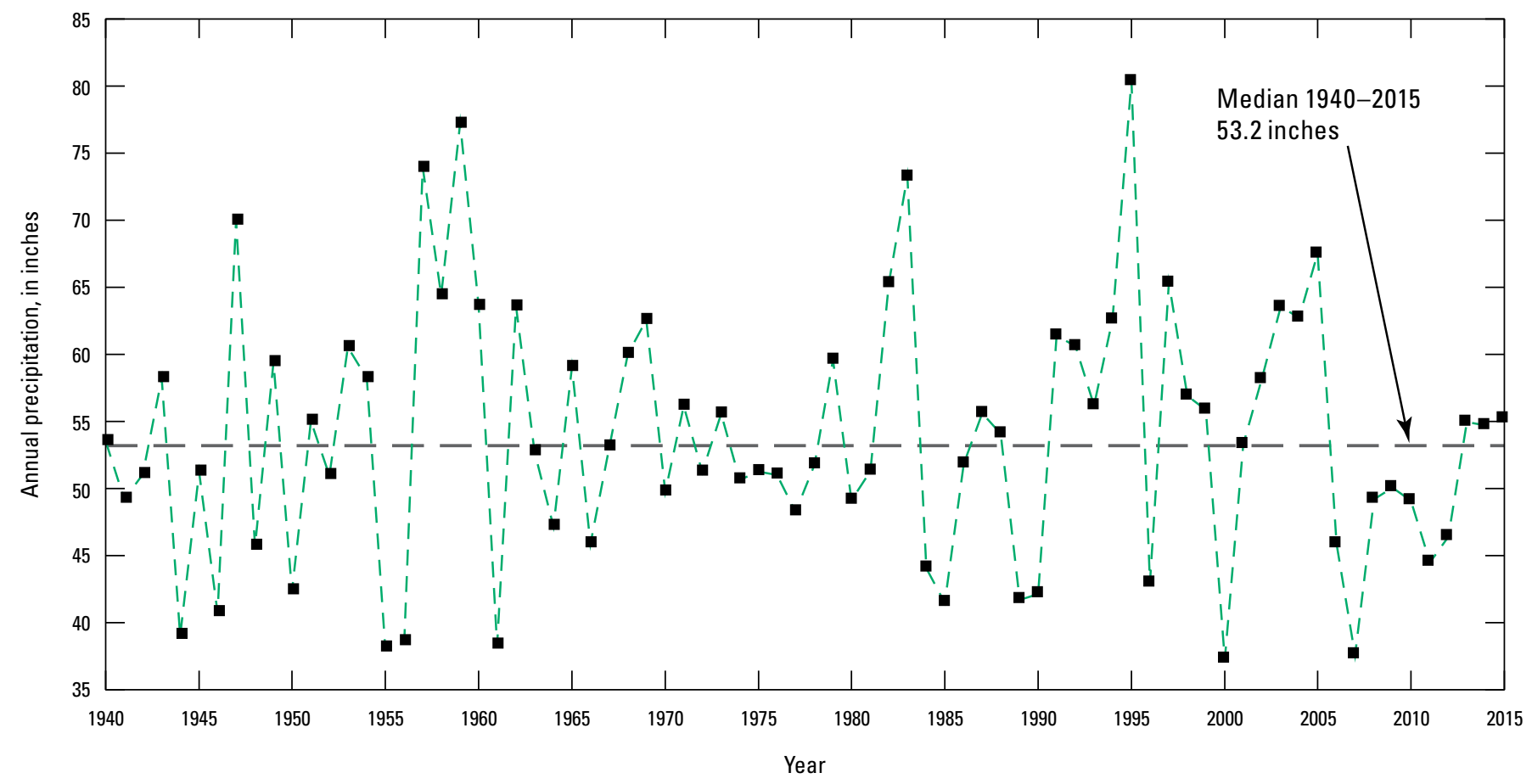

Figure 3. Annual precipitation in the Myakka River Basin, 1940-2015. Data source is the Southwest Florida Water Management District (2016b). 


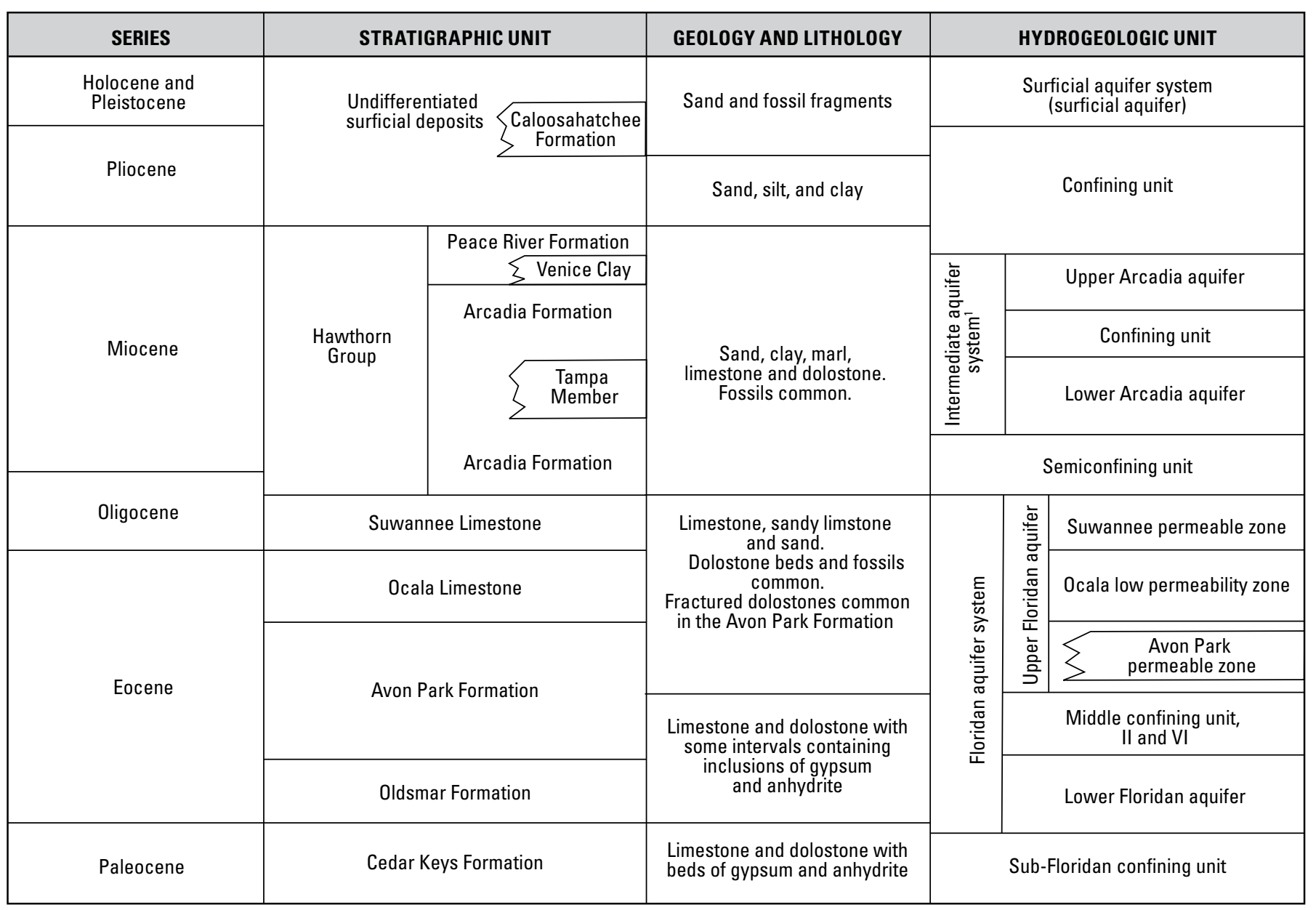

${ }^{1} A$ proposed revision by DeWitt and Mallams (2007) and Mallams and DeWitt (2007) replaces zone 2 and zone 3 from Knochenmus (2006) with the upper and lower Arcadia aquifers, respectively. This revision also proposes to rename the intermediate aquifer system in southwestern Florida to the Hawthorn aquifer system (excluding the upper and lower confining units). There is not a current consensus, however, on the use of "Hawthorn aquifer system," so in this report only the proposed upper and lower Arcadia aquifer names are used.

Figure 4. Relation of stratigraphic and hydrogeologic units of the Florida Platform in central Florida (modified from Metz and Lewelling, 2009; Clayton, 2010).

fractures. Eventually, with continued enlargement of these features, sinkholes can form. Such features constitute a major part of the porosity and permeability of carbonate aquifers in Florida (Williams and Kuniansky, 2015).

The Warm Mineral Springs pool has a circular shape (fig. 2) and was created when the sinkhole formed in the sand, clay, and dolostone of the Arcadia Formation (Rupert, 1994; fig. 5A). A debris cone, which measures about $225 \mathrm{ft}$ wide and $125 \mathrm{ft}$ thick, covers much of the bottom of Warm Mineral Springs and formed from material that collapsed into the sinkhole (Cockrell, 1990; Rupert, 1994). Several of the largest springs in Florida (Silver Springs, Homosassa Springs, and Wakulla Springs; fig. 1) probably originated as sinkholes that became springs as a result of rising groundwater and sea levels during the Holocene Epoch (since 11.7 thousand years ago [ka]; Upchurch and Randazzo, 1997).
Numerous flowstones or stalactites and water channels are present on the carbonate walls that are currently (2016) below the pool surface of Warm Mineral Springs, indicating exposure to air and flow of water down the exposed wall at some time in the past (fig. $5 A, B$ ). The water level during the Late Pleistocene was initially estimated as at least $75 \mathrm{ft}$ below the spring pool surface (Clausen and others, 1975). A later report by Cockrell (1990) indicated the Late Pleistocene water level to be at $100 \mathrm{ft}$ (30 meters) below the modern spring pool surface at about $12 \mathrm{ka}$ on the basis of plant material and radiometric dating of human remains found in the sink (fig. 5A). As sea level rose during the Holocene Epoch, groundwater levels also rose, and Warm Mineral Springs gradually filled with mineralized groundwater. Collapsed geologic features and structural anomalies have been known to act as preferential avenues for groundwater flow (Spechler, 1994; Metz and Lewelling, 2009; Cunningham, 2013). 
$\boldsymbol{A}$

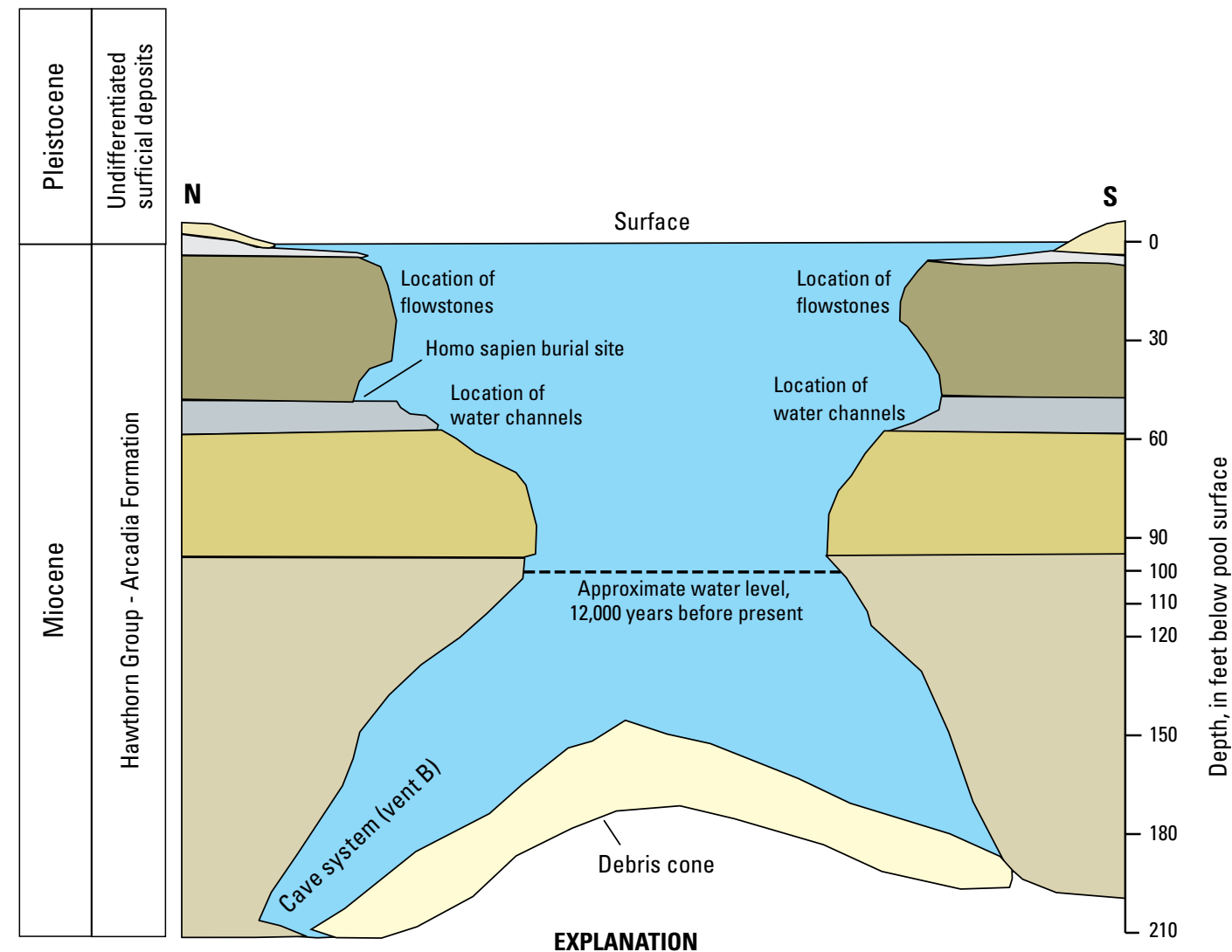

EXPLANATION

$\square$ Surficial sand
$\square$ Gray, sandy dolostone, containing fossils

Greenish-gray to olive green dolostone containing 3 to 5 percent phosphate sand
Greenish-gray dolomitic clay

Yellowish-gray recrystallized dolostone containing phosphatic sand, mollusk molds, and recrystallized echinoid fossils

Yellow-gray to light olive, microcrystalline dolostone containing variable amounts of sand and phosphatic sand, mollusk molds, sporadic vertebrate bones, and benthic foraminifera

\section{B}

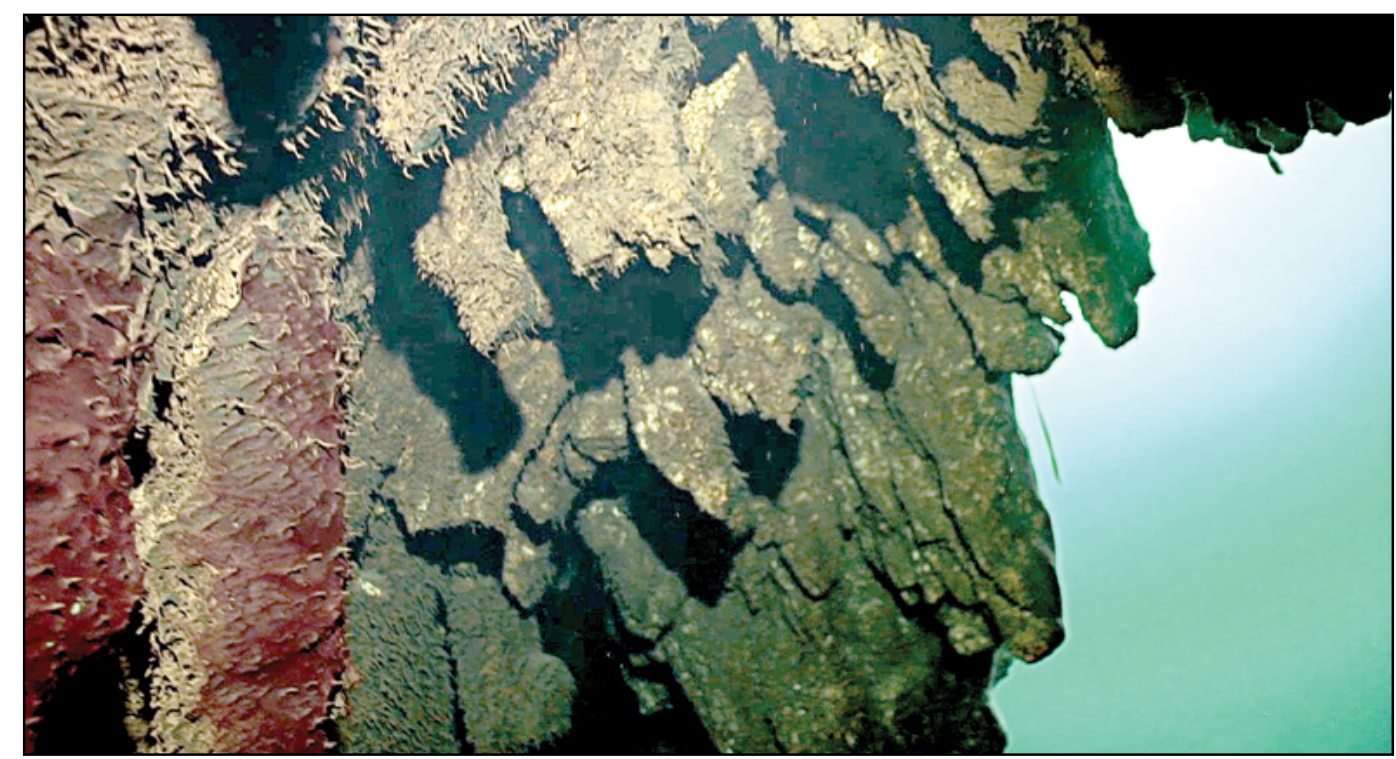

Photograph by Curt Bowen, ADM Exploration Foundation, 2015

Figure 5. A, The geology of Warm Mineral Springs (modified from Rupert, 1994). B, Flowstones located on the walls of Warm Mineral Springs. 


\section{Hydrologic Setting}

The hydrologic units in the Warm Mineral Springs area are described at the ROMP 8 well (fig. $1 A, B$ ), located approximately 1.3 miles north-northeast of Warm Mineral Springs (Clayton, 2010). Exploratory coring in the first phase of the ROMP 8 well construction extended to a depth of $1,283 \mathrm{ft}$ below the land surface (bls). The ROMP 8 well penetrated three aquifers: the surficial aquifer system, the intermediate aquifer system, and the Upper Floridan aquifer. The stratigraphy and corresponding aquifer units for the study area are shown in figure 4. In locations where the geologic units that compose the intermediate aquifer system do not have aquifer properties, this unit is referred to as the upper confining unit. At the ROMP 8 well, the lower most unit of the intermediate aquifer system was considered to be a "semi-confining unit" and not very effective as a confining unit (Clayton, 2010). Underlying the Upper Floridan aquifer is the middle confining unit and the Lower Floridan aquifer (fig. 4).

\section{Regional Groundwater Levels and Water Use of the Upper Floridan aquifer}

Warm Mineral Springs is located in the Southern WestCentral Florida Groundwater Basin (SWCFG Basin), which covers an area of approximately 5,000 square miles (fig. 6). Lateral flow paths of groundwater can be estimated from the configuration of the potentiometric surface of the Upper Floridan aquifer. The potentiometric surface for the Upper Floridan aquifer for September 2010 (Ortiz, 2011) for the approximate area of the SWCFG Basin indicates a relative high to the north and east (areas of recharge in Polk and Highlands Counties) and a relative low to the west and south (areas of discharge in Manatee, Sarasota, DeSoto, and Charlotte Counties; fig. 6).

Groundwater flow paths inferred from the configuration of the potentiometric surface for September 2010 are generally from areas of recharge (in Polk and Highlands Counties) to areas of discharge (in Manatee, Sarasota, DeSoto, and Charlotte Counties). Warm Mineral Springs is located in an area with the potential for discharge to the surface.

Analysis of a series of ROMP wells along a cross-section line (fig. 6) were used to assess the groundwater flow patterns in the region of Warm Mineral Springs. Water levels indicate that the ROMP 13 and 14 wells were in an area of recharge, and the ROMP 8, 9, 12, and 16.5 wells were located in an area of discharge (fig. 6). Mean annual water levels for 2007-15 in ROMP wells were analyzed for the surficial aquifer system, Peace River Formation, upper Arcadia aquifer, and Upper Floridan aquifer (Suwannee Limestone and Avon Park Formation). Artesian conditions from the Upper Floridan aquifer were indicated for wells located in discharge areas: ROMP 8 , 9, 12 and 16.5 (table 1). The ROMP 8 and 9 wells, located closer to the coast, had water levels for the Upper Floridan aquifer that were 15 to $19 \mathrm{ft}$ above land surface, respectively. On the basis of these ROMP groundwater levels, there is an increase in the potential for groundwater discharge in areas closer to the coast. Ryder (1985) developed a steady-state model of groundwater flow for west-central Florida. Along a cross section approximately 30 miles north of Warm Mineral Springs (figure 19 of Ryder, 1985), groundwater flow was simulated as downward from the surface and intermediate aquifer systems into the Upper Floridan aquifer in inland areas (Hardee and Polk Counties), and upward groundwater flow from the Upper Floridan aquifer was simulated in coastal regions, such as Sarasota County.

Groundwater from the Upper Floridan aquifer is the largest component of the water supply in the counties within the SWCFG Basin, (Marella, 2014). The 10-year moving average for estimated groundwater withdrawal during 1991-2010 in the SWCFG Basin was about 650 million gallons per day (Mgal/d), which represents a twofold increase from the 1950s; much of the increase occurred from the 1950s to the 1970s (fig. 7A). In contrast, total groundwater use in Sarasota County has had no significant temporal trend from 1965 to 2010 (estimated every 5 years), with significance based on the Kendall's tau non-parametric test (fig. 7B). Water use from groundwater sources (as a fraction of total water use) in Sarasota County ranged from 98 percent in 1965 to 78 percent in 1995.

Decreased water use in 1995 was associated with the maximum annual precipitation for the period 1940-2015 (fig. 3).

Declines in groundwater levels occurred within the SWCFG Basin from the 1930s to the 1970s as a result of water withdrawals for phosphate mining in the northern part of the basin (Polk County) and other uses (Metz and Lewelling, 2009). In the area of Warm Mineral Springs, the historical increase in groundwater withdrawals, and other factors (sometimes counteracting withdrawals) such as weather conditions and agricultural conservation, resulted in a 10- to 20 -ft decline in the potentiometric surface of the Upper Floridan aquifer by May 1975 relative to predevelopment levels (fig. 8); water levels remained at approximately the May 1975 level in May 2007 (Metz and Lewelling, 2009, p. 32). Despite stabilization of groundwater levels since the 1970s, depressed aquifer levels have resulted in secondary effects, such as saltwater intrusion and lowered lake levels in the region (Southwest Florida Water Management District, 2016c).

\section{Discharge}

Historical measurements of discharge were made on Warm Mineral Springs Creek (fig. 2), which flows southwestward to Salt Creek and eventually into the Myakka River (fig. 1A). While Warm Mineral Springs is classified as a thirdmagnitude spring $\left(1-10 \mathrm{ft}^{3} / \mathrm{s}\right)$, recorded flows at Warm Mineral Springs Creek have exceeded $10 \mathrm{ft}^{3} / \mathrm{s}$. Ten instantaneous discharge measurements from 1942 to 1974 averaged $9.7 \mathrm{ft}^{3} / \mathrm{s}$ and exceeded $10.0 \mathrm{ft}^{3} / \mathrm{s}$ in 3 of 10 years. Discharge measurements since 1971 have been less than $10 \mathrm{ft}^{3} / \mathrm{s}$ (table 2; fig. 9). Measurements of discharge at Warm Mineral Springs Creek are sparse for the time period 1942-2014, but changes over 


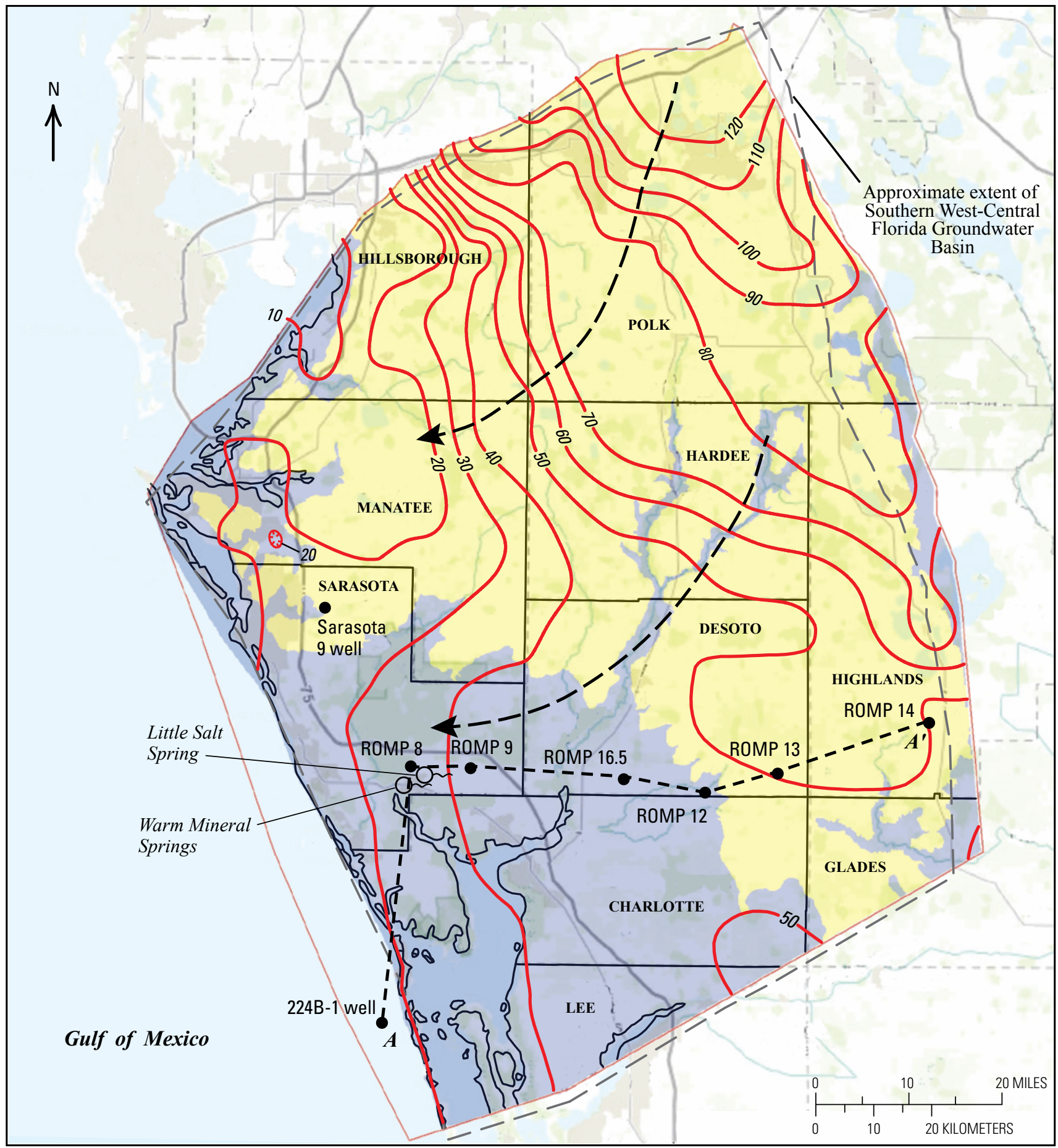

Base modified from Esri, DeLorme, HERE, TomTom, Intermap, increment P Corp., GEBCO, USGS, FAO, NPS, NRCAN, GeoBase,

IGN, Kadaster NL, Ordnance Survey, Esri Japan, METI, Esri China (Hong Kong), swisstopo, and the GIS User Community

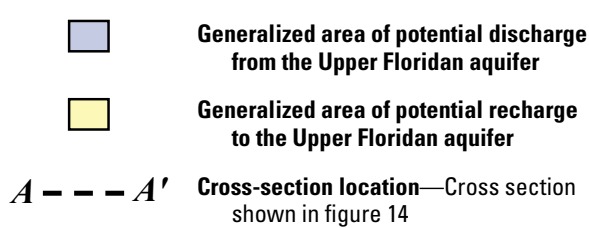
shown in figure 14
EXPLANATION

\section{- 50- Potentiometric-surface contour-Shows level that water would have stood in tightly cased wells tapping the Upper Floridan aquifer, in feet. Interval 10 feet. Datum is NGVD 29 (modified from Ortiz, 2011) \\ Generalized groundwater flow paths \\ Location of selected wells used in the study-Regional Observation Monitor-Well Program (ROMP)}

Figure 6. Area of recharge and discharge, potentiometric surface of the Upper Floridan aquifer for September 2010, generalized groundwater flow path in the Southern West-Central Florida Groundwater Basin, and location of wells used in this study (modified from Ortiz, 2011). 
Table 1. Water levels above or below land surface for selected Regional Observation Monitor-Well Program (R0MP) wells, 2007-15, stored by the Southwest Florida Water Management District (2016c).

[Location of wells shown in figure 6. SWFWMD, Southwest Florida Water Management District; ID, identification; ft, foot; SA, surficial aquifer; IAS, intermediate aquifer system; UFA, Upper Floridan aquifer; - , conditions did not occur]

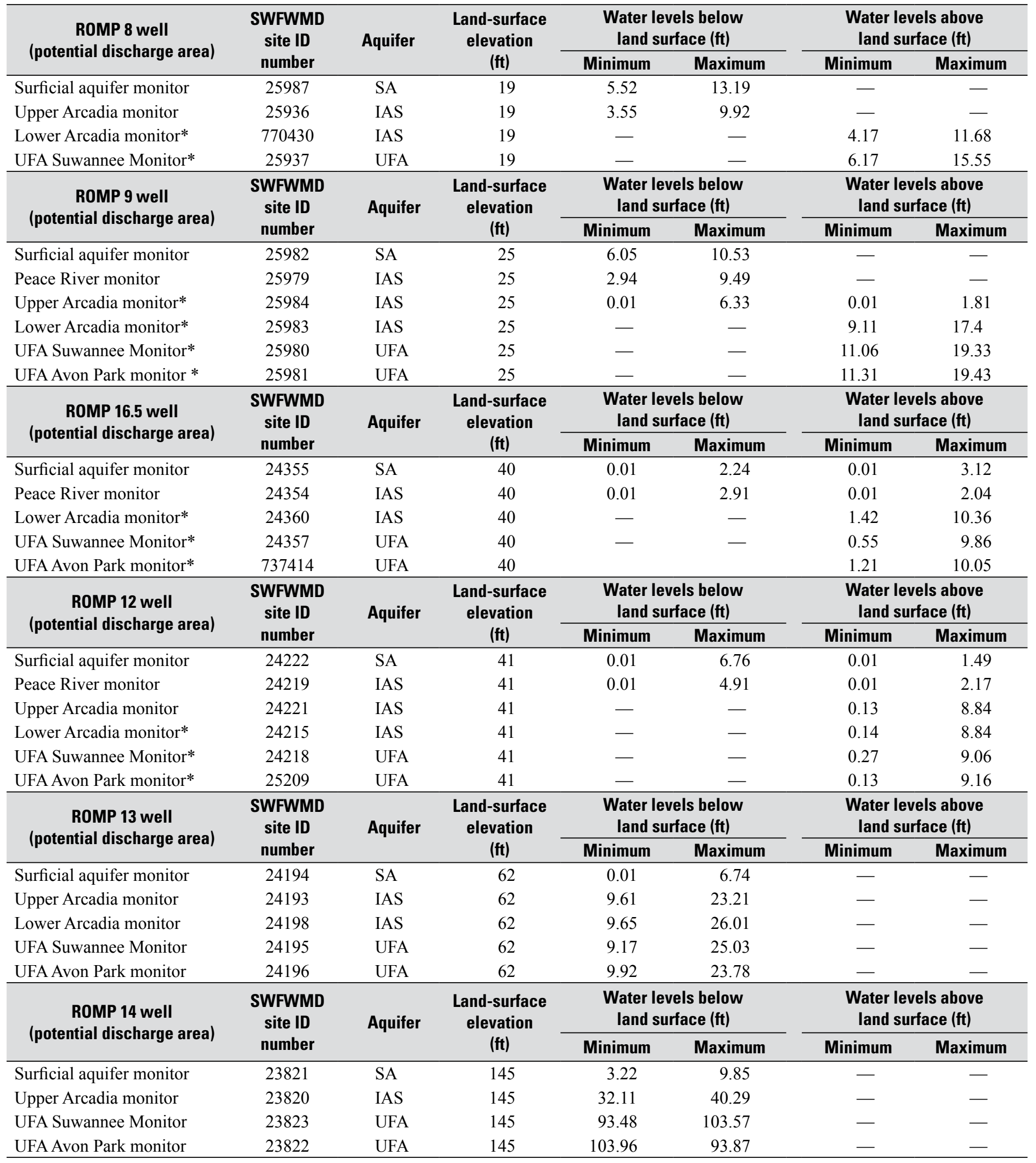

\footnotetext{
*Water levels were adjusted to correct for saltwater density differences, using methods by Guo and Langevin (2002).
} 


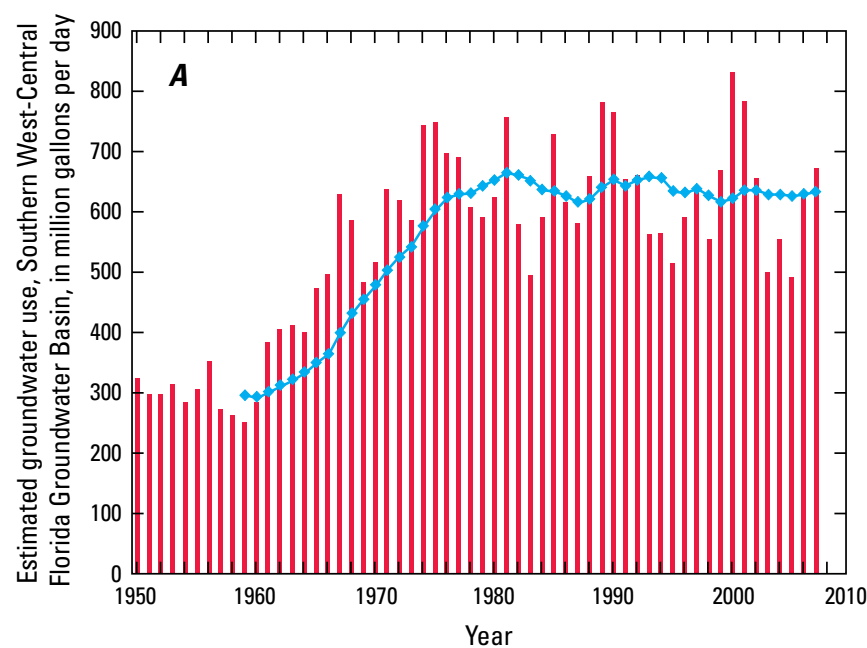

EXPLANATION

I Estimated groundwater use-Excluding Charlotte, Glades, and Lee Counties (Southwest Florida Water Management District, written commun., 2009)

-10 year moving average

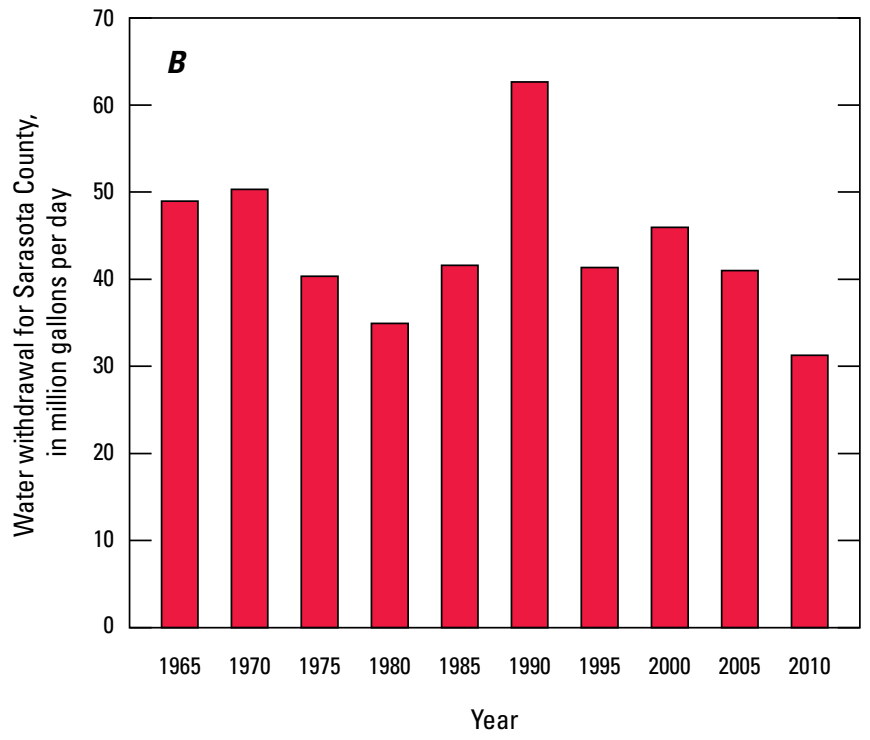

Figure 7. A, Estimated groundwater use in the Southern West-Central Florida Groundwater Basin (adapted from Metz and Lewelling, 2009). $B$, Estimated groundwater use in Sarasota County.

A. May 1975

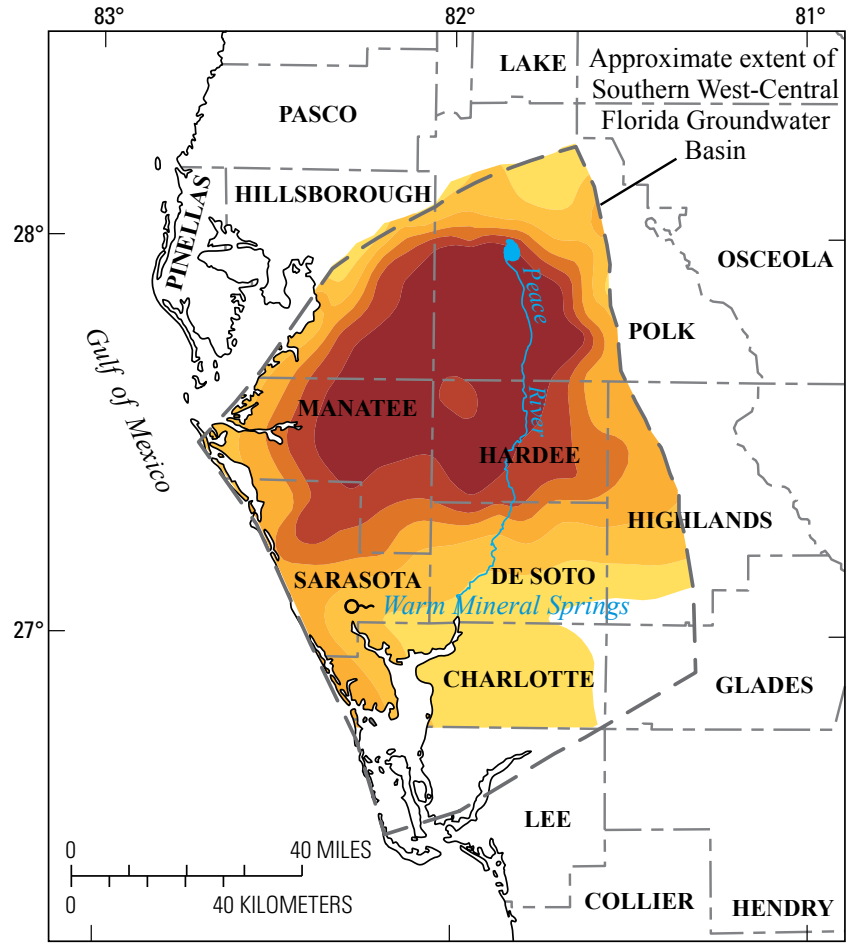

Base modified form ESRI ArcGIS online data base: 1:100,000, 2014, World Geodetic System of 1984

\section{B. May 2007}

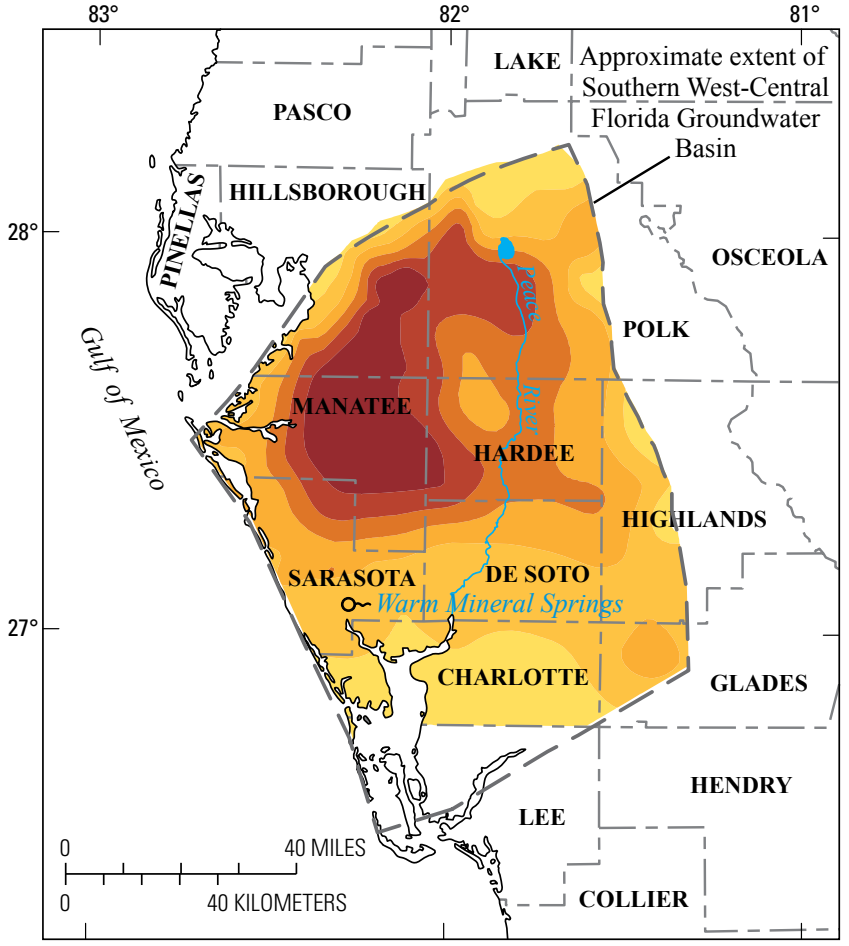

Base modified form ESRI ArcGIS online data base: 1:100,000, 2014, World Geodetic System of 1984

EXPLANATION

Decrease in the potentiometric surface levels of the Upper Floridan aquifer, in feet-Based on predevelopment levels (Johnston and others, 1980) and May 2007 levels (Ortiz, 2008)

\begin{tabular}{l|l|l}
$>50$ & $>30$ to 40 & $>10$ to 20 \\
$>40$ to 50 & $>20$ to 30 & 0 to 10
\end{tabular}

Figure 8. Change in the potentiometric surface of the Upper Floridan aquifer between predevelopment levels (Johnston and others, 1980) and May 1975 levels (Mills and Laughlin, 1976), and change between predevelopment levels and May 2007 levels (Ortiz, 2008) levels (modified from Metz and Lewelling, 2009). 
this time period are indicated. Discharge decreased from about $11-12 \mathrm{ft}^{3} / \mathrm{s}$ in the $1940 \mathrm{~s}$ to about $6-9 \mathrm{ft}^{3} / \mathrm{s}$ in the $1970 \mathrm{~s}$, and remained mostly at that level for the remainder of the period of record. This pattern of decrease until about the 1970s is consistent with the trend of water withdrawals for the SWCFG Basin, previously discussed in the "Regional Groundwater Levels and Water Use" section, which indicates that basinscale changes to the groundwater system, such as groundwater use, have affected discharge at Warm Mineral Springs.
There are five known vents or solution conduits in the northern half of the spring bottom (Rupert, 1994; Bowen, 2015; fig. 10A). The largest vent (vent B), and the primary inflow to the spring, emanates from a cave that extends about $174 \mathrm{ft}$ (53 meters) into the Arcadia Formation and descends slightly downward to a depth of about $220 \mathrm{ft}$ (67 meters) below the pool surface (Rupert, 1994). The largest part of the vent is at the end of the cave, which opens into a room that measures about $33 \mathrm{ft}$ long by $10 \mathrm{ft}$ high by $10 \mathrm{ft}$ wide.

Table 2. Instantaneous discharge and water temperature measurements made at Warm Mineral Springs outlet (1942 to 2015) and average, annual water levels for the Upper Floridan aquifer.

[NGVD 29, National Geodetic Vertical Datum of 1929; USGS, U.S. Geological; —, no data or not applicable; SWFWMD, Southwest Florida Water Management District; HDC, Hydrologic Data Collection, Inc. (http://www.hydrologicdata.com/)]

\begin{tabular}{|c|c|c|c|c|c|}
\hline Agency or report & Site number & $\begin{array}{c}\text { Date of } \\
\text { measurement }\end{array}$ & $\begin{array}{l}\text { Discharge, in } \\
\text { cubic feet per } \\
\text { second }\end{array}$ & $\begin{array}{c}\text { Water } \\
\text { temperature, } \\
\text { in degrees } \\
\text { Fahrenheit }\end{array}$ & $\begin{array}{l}\text { Average annual } \\
\text { Upper Floridan } \\
\text { aquifer levels, } \\
\text { in feet above } \\
\text { NGVD } 29^{1}\end{array}$ \\
\hline USGS & 02299260 & $10 / 1 / 1942$ & 11.7 & - & 32.54 \\
\hline Rosenau and others (1977) & - & $8 / 11 / 1943$ & - & 86.0 & 32.40 \\
\hline USGS & 02299260 & $4 / 29 / 1946$ & 10.8 & - & 32.37 \\
\hline USGS & 02299260 & $4 / 24 / 1956$ & 9.5 & 87.8 & 30.10 \\
\hline USGS & 02299260 & $12 / 14 / 1960$ & 9.0 & 84.2 & 30.47 \\
\hline USGS & 02299260 & $2 / 22 / 1962$ & 9.4 & 86.0 & 28.03 \\
\hline USGS & 02299260 & $4 / 9 / 1962$ & 10.0 & 84.0 & 28.03 \\
\hline USGS & 02299260 & $6 / 7 / 1962$ & 9.3 & 87.8 & 28.03 \\
\hline USGS & 02299260 & $6 / 15 / 1962$ & - & 77.0 & 28.03 \\
\hline USGS & 02299260 & $11 / 22 / 1971$ & 11.2 & - & 23.76 \\
\hline USGS & 02299260 & $4 / 24 / 1972$ & -- & 85.1 & 22.97 \\
\hline USGS & 270333082154000 & $5 / 31 / 1972$ & 9.2 & 73.4 & 22.97 \\
\hline USGS & 02299260 & $10 / 13 / 1972$ & - & 84.2 & 22.97 \\
\hline Rosenau and others (1977) & - & $5 / 22 / 1974$ & 7.6 & - & 19.36 \\
\hline USGS & 02299260 & $6 / 3 / 1981$ & 6.9 & - & 20.36 \\
\hline USGS-WRD & 02299260 & $11 / 29 / 1984$ & - & 84.2 & 21.97 \\
\hline USGS-WRD & 02299260 & $1 / 31 / 1985$ & 8.8 & 83.3 & 17.68 \\
\hline Scott and others (2004) & DEP FGS-443 & $4 / 3 / 2003$ & 8.5 & 86.4 & 22.88 \\
\hline SWFWMD & 773331 & $8 / 11 / 2009$ & 8.1 & - & 15.64 \\
\hline SWFWMD & 773331 & $2 / 3 / 2011$ & 7.0 & - & 15.99 \\
\hline SWFWMD & 773331 & $7 / 20 / 2011$ & 8.1 & - & 15.99 \\
\hline HDC & - & $5 / 2 / 2012$ & 5.4 & - & 13.48 \\
\hline HDC & - & $6 / 6 / 2012$ & 6.5 & - & 13.48 \\
\hline HDC & - & $7 / 11 / 2012$ & 6.8 & - & 13.48 \\
\hline HDC & - & $8 / 22 / 2012$ & 6.7 & - & 13.48 \\
\hline HDC & - & $9 / 28 / 2012$ & 7.2 & - & 13.48 \\
\hline SWFWMD & 773331 & $7 / 30 / 2013$ & 8.8 & - & 17.22 \\
\hline USGS & 02299260 & $4 / 11 / 2014$ & 8.3 & - & 18.64 \\
\hline Sarasota County (2016b) & - & $4 / 29 / 2015$ & - & 84.5 & 20.00 \\
\hline
\end{tabular}

${ }^{1}$ Sarasota 9 well (USGS site number 271938082251801 and SWFWMD site number 25682). 


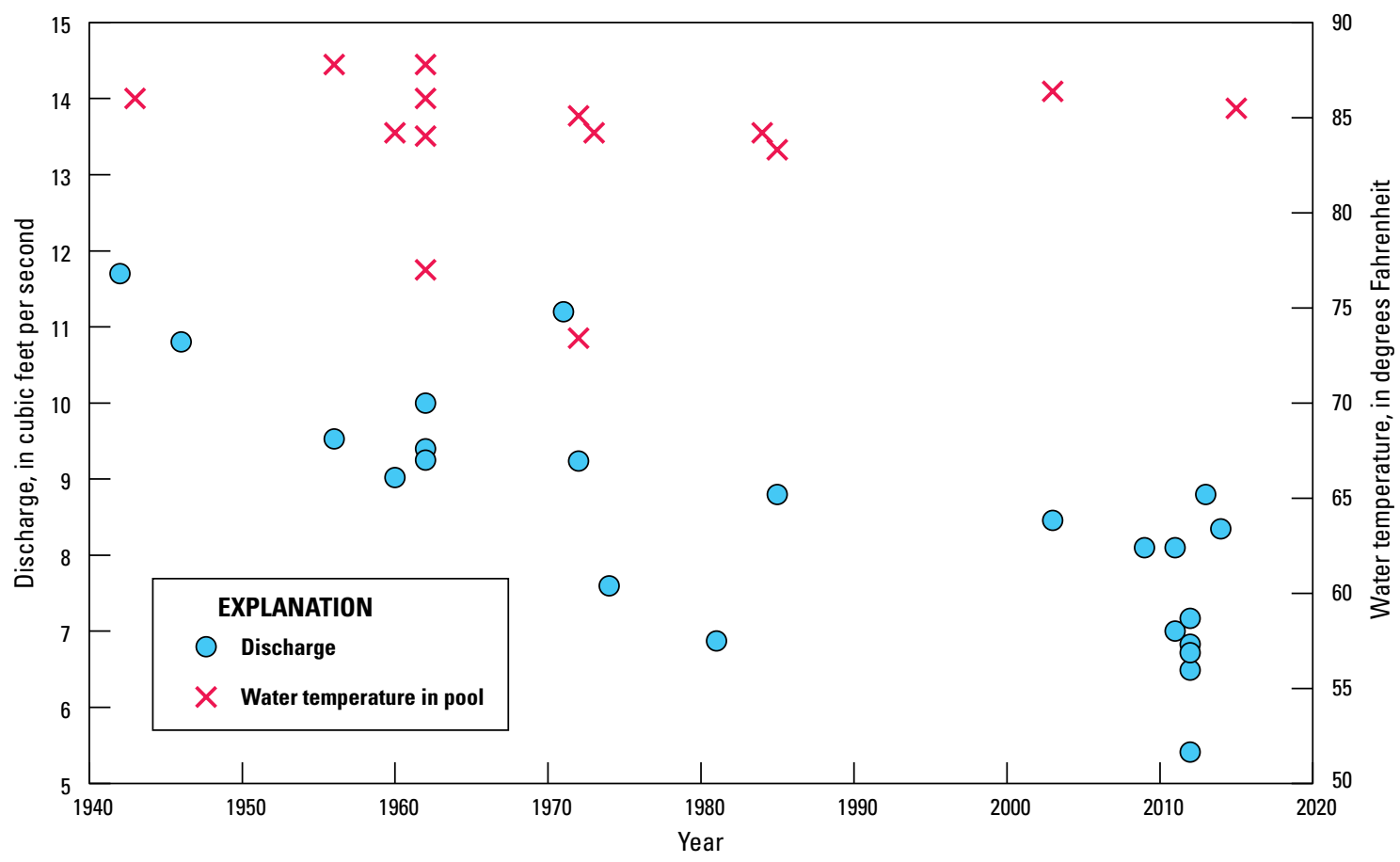

Figure 9. Instantaneous discharge and water temperature measurements at Warm Mineral Springs, 1942-2015.

The discharge at the end of the cave was observed by Rupert (1994) as diffuse upward flow from the cavern floor.

One discharge measurement (1971) of approximately $30 \mathrm{ft}^{3} / \mathrm{s}$ was made by divers at vent $\mathrm{B}$ at a depth of $205 \mathrm{ft}$ (fig. 10B) on November 22, 1971. Discharge was computed by approximating cave cross-sectional area and measuring the velocity of fluorescein dye over a 15-ft length of the vent cave (Kohout and others, 1977). The instantaneous measurement of spring discharge at the outlet for that day was $11.2 \mathrm{ft}^{3} / \mathrm{s}$ and was the second highest discharge recorded (table 2). Given the uncertainty of measuring velocity at the vent using fluorescein dye methods and uncertainty in vent geometry, conclusions regarding processes to explain the apparent differences in vent and surface discharge are not possible. A second measurement at vent B was attempted in May 1974, but velocity was very low ( 0.1 foot per second $)$ and the discharge estimate was not considered valid for this analysis. The instantaneous measurement of spring discharge on May 22, 1974, was $7.6 \mathrm{ft}^{3} / \mathrm{s}$. Kohout and others (1977) indicated that the 1974 measurement was taken following a dry season, and suggested that flow from vents might be variable. In addition to warm vents, cool-water vents discharge from the walls of the spring. Bowen (1996) reported cool vents at depths of $198 \mathrm{ft}$ $\left(76^{\circ} \mathrm{F}\right)$ and $8 \mathrm{ft}$. Cool vents could be used to infer that water is discharging from shallower aquifers, such as the intermediate aquifer system, into the spring.

\section{Water Level in the Sarasota 9 Well and Relation to Spring Discharge}

The relation was assessed between water levels of the Upper Floridan aquifer for the Sarasota 9 well (fig. 1) and the spring discharge at Warm Mineral Springs for 1942-2014. The Sarasota 9 well was the only Upper Floridan aquifer well in Sarasota County with long-term water level data (1931-2015), and water levels in this well are influenced by groundwater use. The annual mean of water levels was used to adjust for changes in water within a given year. The annual mean water level of the Upper Floridan aquifer at the Sarasota 9 well exhibits a pattern of decline since the 1950 s, with the rate of decline decreasing following the 1980s to current (2015) levels (fig. 11).

A significant linear relationship exists between the mean annual (if more than one measurement in a year) or instantaneous (if only one measurement in a year) discharge measurements at Warm Mineral Springs and the annual mean water level at the Sarasota 9 well (fig. 12). Uncertainty in estimates from the linear regression is reflected in the coefficient of determination $\left(\mathrm{R}^{2}\right)$ for the regression of 0.58 . Uncertainty is also indicated by analysis of residuals (predicted value minus observed), which had a standard deviation of $0.6 \mathrm{ft}^{3} / \mathrm{s}$, or about 7 percent of the mean annual discharge of $8.5 \mathrm{ft}^{3} / \mathrm{s}$ for 1942-2014. 
A

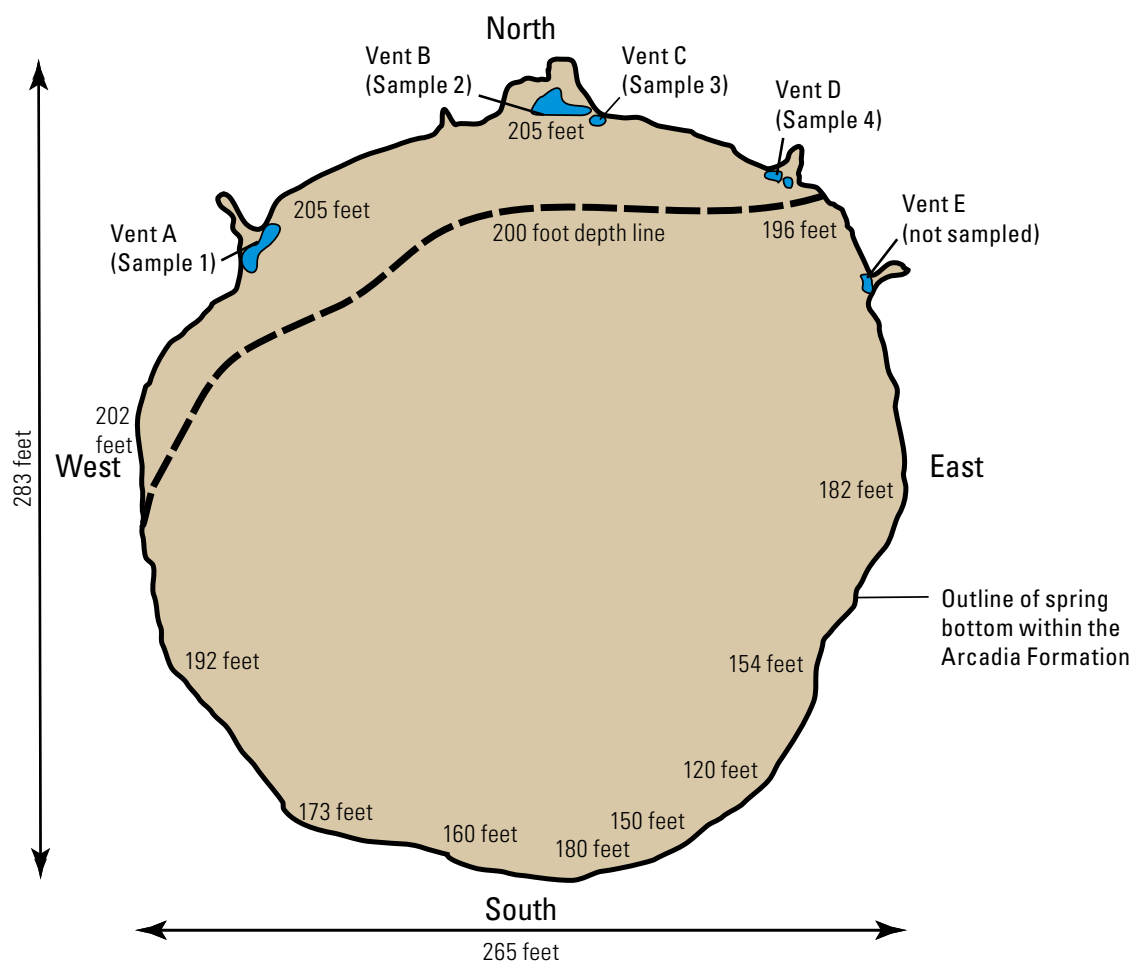

B

Vent A

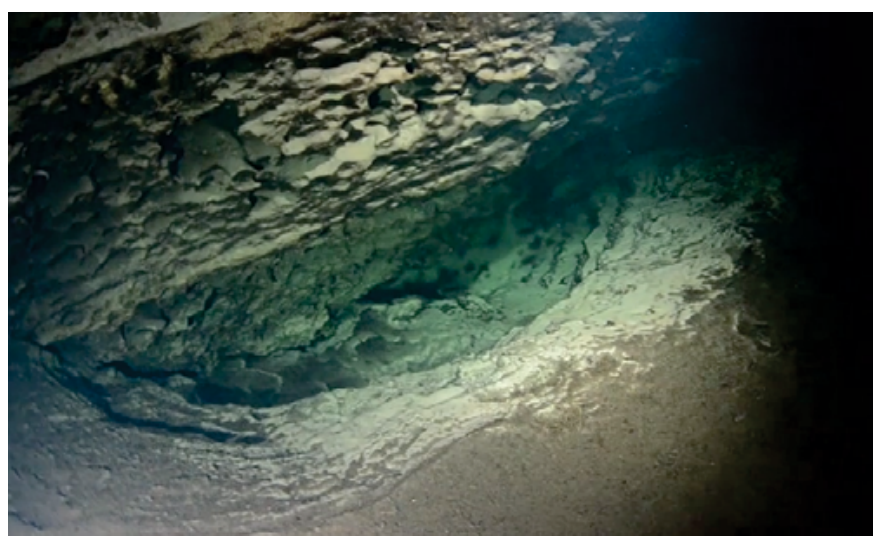

Vent $B$ (near the end of $174 \mathrm{ft}$ long conduit system)

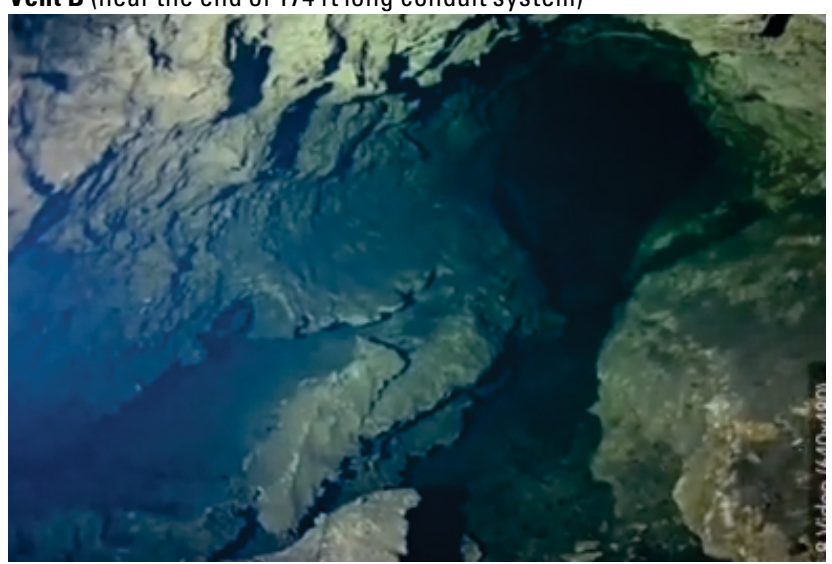

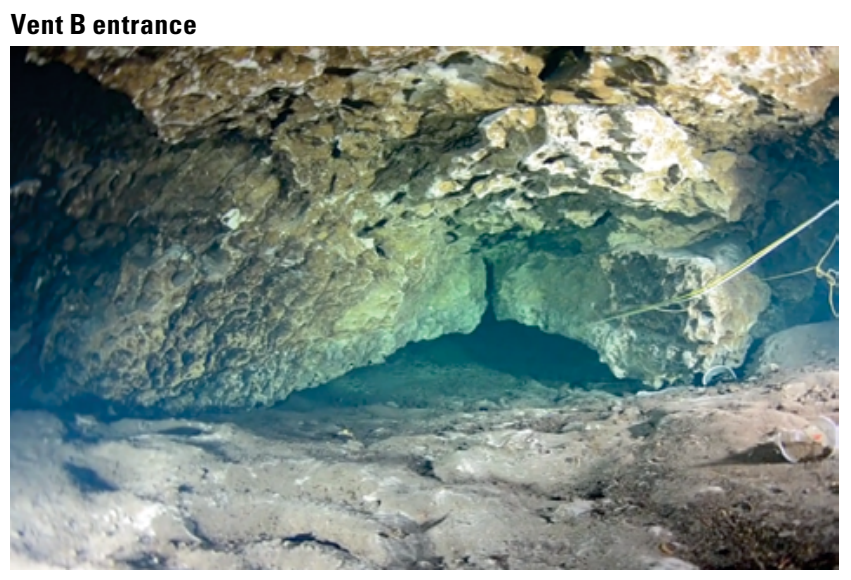

Vent D

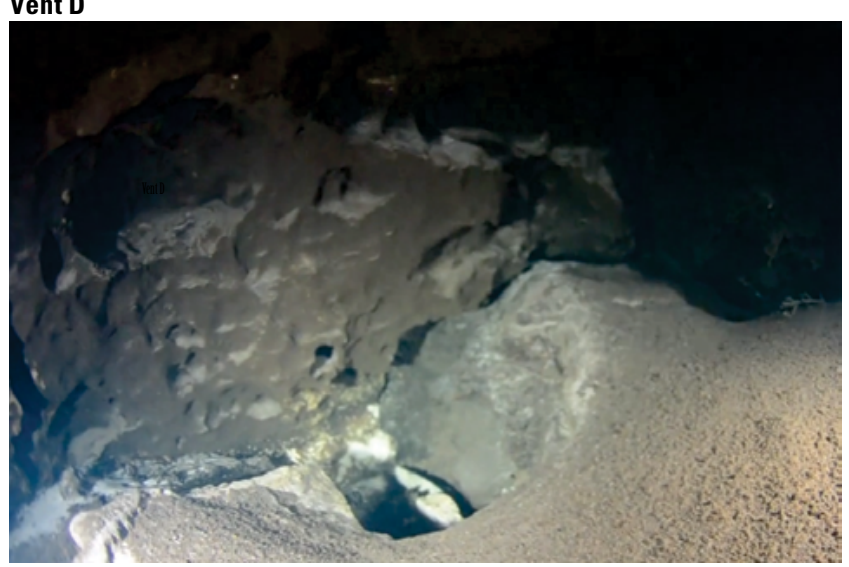

Figure 10. A, Diagram of the bottom of Warm Mineral Springs showing the location of spring vents A-E (modified from Bowen, 2015). $B$, Photographs showing some of the spring vents (photographs by Curt Bowen, ADM Exploration Foundation, 2015). 


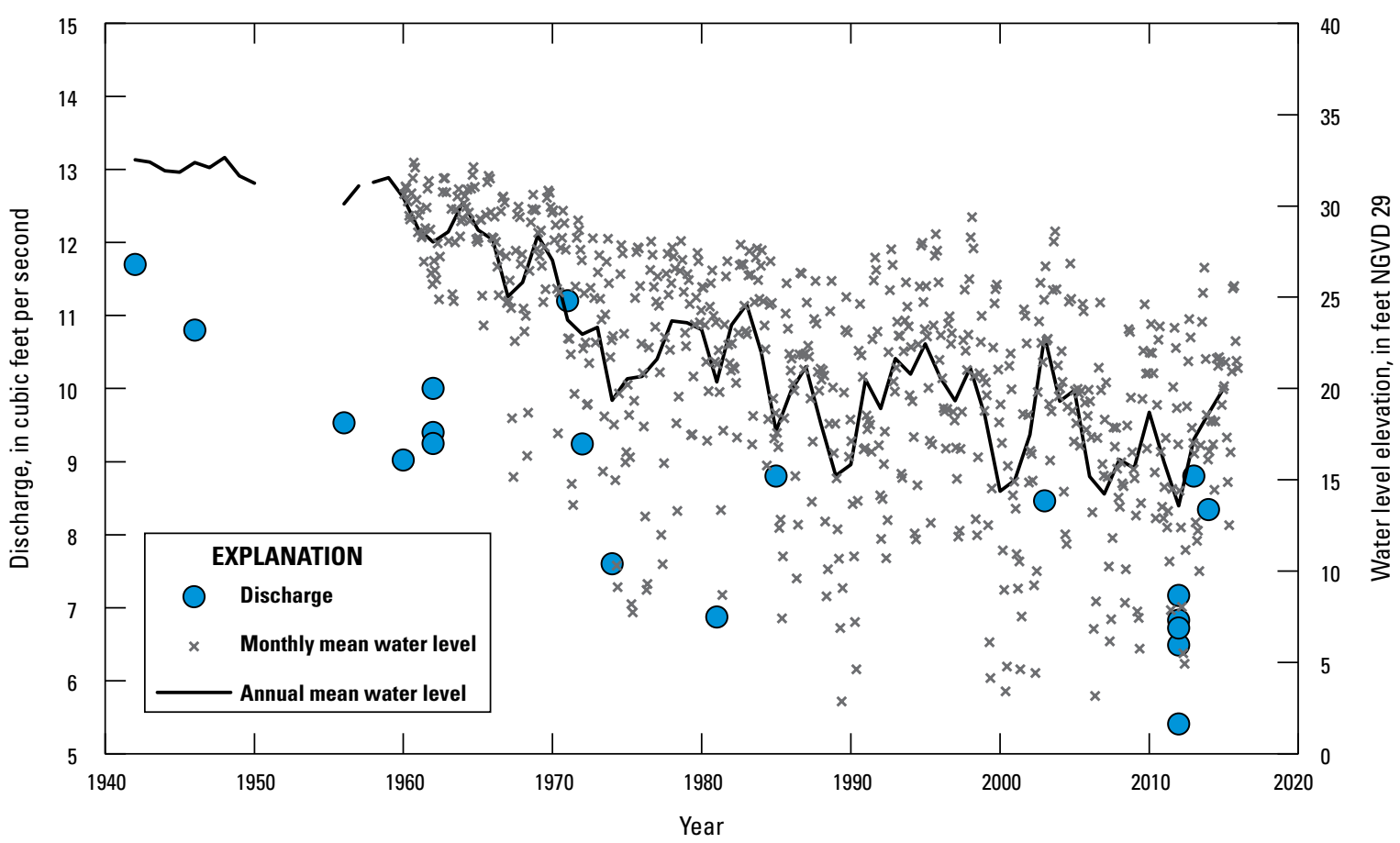

Figure 11. Time series of instantaneous discharge at Warm Mineral Springs and annual mean and monthly water-level elevation of the Upper Floridan aquifer in the Sarasota 9 well.

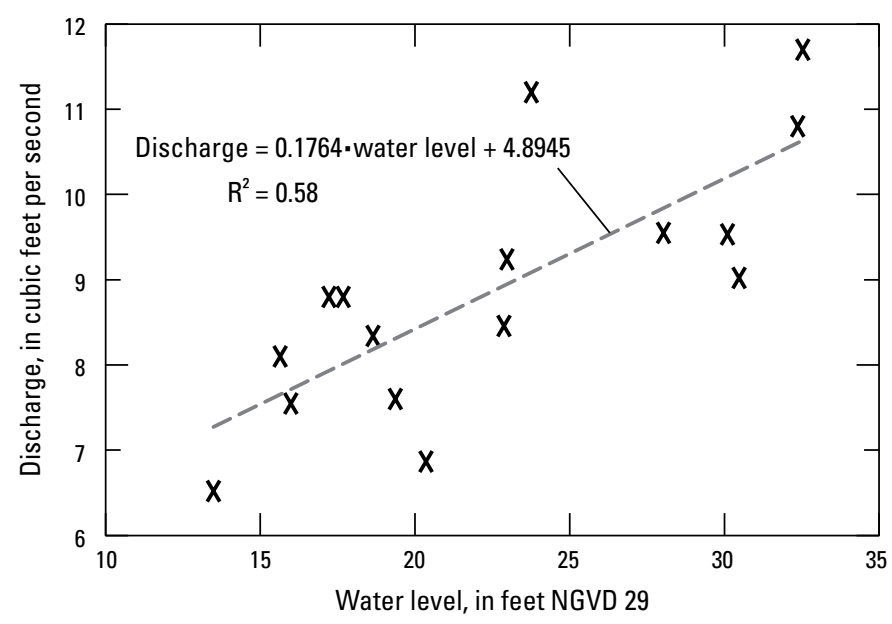

Figure 12. Annual mean or instantaneous discharge at Warm Mineral Springs and water-level elevation of the Upper Floridan aquifer in the Sarasota 9 well.

Given the uncertainty of simple linear models, understanding the relation between discharge and aquifer water levels could be improved with continuous discharge measurements at Warm Mineral Springs. The proximity of the ROMP 8 well makes it a valuable resource for developing relationships between discharge at Warm Mineral Springs and aquifer levels, providing local water levels for the surficial aquifer, upper Arcadia aquifer, and Upper Floridan aquifer (Suwannee Limestone; Southwest Florida Water Management District, 2016a).

\section{Water Temperature}

Temperature was discontinuously measured at the Warm Mineral Springs pool, with 14 measurements made over the period 1943-2015. Historic temperature readings at Warm Mineral Springs (table 2; fig. 9) ranged from $73.4^{\circ} \mathrm{F}$ (1972) to $87.8^{\circ} \mathrm{F}(1956,1962)$. Low temperature readings of $77.0^{\circ} \mathrm{F}$ and $73.4^{\circ} \mathrm{F}$, during 1962 and 1972, respectively, are outliers. For example, a reading of $87.8^{\circ} \mathrm{F}$ on June 7,1962 , was followed by a reading of $77^{\circ} \mathrm{F}$ on June 15,1962 . The reading of $73.4^{\circ} \mathrm{F}$ in May 31,1972 , is bracketed by readings of $85.1^{\circ} \mathrm{F}$ and $84.2^{\circ} \mathrm{F}$ during 1972 . The variability might reflect readings taken at different locations, but the reason for these outliers was not determined. Sparseness of temperature data makes identification of outliers difficult; continuously monitored temperature from a consistent location would allow for identification of outliers as valid or invalid readings, and increase confidence in future measurements. There was no significant trend in temperature over the period of record, based on the Kendall's tau test, whether the outliers noted above were included or deleted in the analysis.

Water temperature readings were recorded once a year from 2011 to 2016 for the outlet channel of Warm Mineral Springs by the Southwest Florida Water Management District (2016a; station number 773331) and ranged from 86 to $89^{\circ} \mathrm{F}$. An indirect comparison of the outlet with pool temperatures can be made for temperature readings in 2015. Pool temperatures on March 18 and August 29 were about 83 and $86^{\circ} \mathrm{F}$, respectively, whereas the outlet temperature measurement on July 28 was about $87^{\circ} \mathrm{F}$. Temperatures from 1995 to 2015 
were also recorded by the Southwest Florida Water Management District (2016a) from water samples collected from the spring (station number 25993); however, samples were pumped to the surface and exposed to the air temperature and would therefore not be representative of pool temperatures (D. Dewitt, Southwest Florida Water Management District, oral commun., 2016). These temperature measurements are not discussed further herein.

There are several vents in Warm Mineral Springs, both cool and warm. Clausen and others (1975) report that there were nine cool $\left(73^{\circ} \mathrm{F}\right)$ and two major hot water $\left(99^{\circ} \mathrm{F}\right)$ vents along the bottom of the northern spring wall at a depth of about $200 \mathrm{ft}$. Clausen and others (1975) also discuss the intermixing of the cool and warm waters that produce a year-round uniform temperature of about $88^{\circ} \mathrm{F}$ in the upper two-thirds of the water column. Bowen (1996) reports there is a cool water inflow vent at 8 and $198 \mathrm{ft}$ below the spring surface on the southwest side of the pool. Bowen (1996) reports temperatures of $97^{\circ} \mathrm{F}$ for the two major bottom hot water vents.

Temperature sensors were attached to two divers on a descent to the bottom of Warm Mineral Springs on April 29, 2015 (Sarasota County, 2016b). Temperature readings near the pool surface were about $85-86^{\circ} \mathrm{F}$ and increased to about $88^{\circ} \mathrm{F}$ at the major bottom vent at $205 \mathrm{ft}$ (vent B; table 3; figs. 10A, $10 B$, and 13). Other vents (A, C, and D) had similar temperatures of 87 to $88^{\circ} \mathrm{F}$. During the dive, diver 1 moved farther (10 to $20 \mathrm{ft}$ ) into the vents than diver 2, resulting in a slight increase in temperature as the diver moved farther into the conduit of the vents (fig. 13) These temperatures are similar to the temperatures measured during water-quality sampling events in 1973 by Kohout and others (1977) and in 1992 by Sacks and Tihansky (1996): $90^{\circ} \mathrm{F}$ and $88^{\circ} \mathrm{F}$, respectively. The decrease in water temperature of about $3.4^{\circ} \mathrm{F}$ from the bottom to the surface ( 87.9 to $84.5^{\circ} \mathrm{F}$ ) as measured by divers is consistent with warm water from vents mixing with cooler groundwater from shallower aquifer sources. Groundwater samples at the ROMP 8 well had water temperatures ranging from 78 to $80^{\circ} \mathrm{F}$ between 10 and $205 \mathrm{ft}$ bls (Clayton, 2010).

There are a number of hypotheses pertaining to the source of thermal water to springs in Florida. Kohout (1965) proposed that the source of the spring water is from deep, geothermally heated seawater that circulates under the Florida Platform (fig. 1B) from the Gulf of Mexico and the Atlantic Ocean to depths of 3,000 ft and then rises to the surface through fractures in the overlying carbonate rocks. Stringfield (1966) theorized that the source of thermal water is from pre-Miocene seawater trapped beneath Miocene sediments more than 30 million years ago. Vernon (1970) reported that the spring water originates as recharge water along inland ridge areas and becomes mineralized as it moves through rock formations and mixes with trapped seawater along preferential groundwater flow paths. Sproul (1977) described "hot spots" or temperature anomalies in Lee County that appear to be related to upwelling of warmer, highly mineralized water along fracture systems. Using high-resolution seismicreflection data along the east coast of Florida, Popenoe and others (1984), Spechler and Wilson (1997), and Cunningham (2013) documented some deep collapsed geologic features and structural anomalies that act as conduits for groundwater flow. Warm Mineral Springs may be similar to one of these collapsed geologic features where structural anomalies extend into deeper layers and provide an avenue for upwelling of deep groundwater with high temperatures.

Griffin and others (1977) describe a generalized increase in groundwater temperature in Florida from deep oil test wells (greater that $12,000 \mathrm{ft} b l s$ ) of $1^{\circ} \mathrm{F}$ per $100 \mathrm{ft}$, whereas Sproul (1977) and Sproul and others (1972) define a more variable range for shallower well depths ( 225 to $1,045 \mathrm{ft}$ bls) at a rate of $1^{\circ} \mathrm{F}$ per 50 to $150 \mathrm{ft}$ of depth. Analysis of geophysical temperature logs of ROMP wells and well 224B-1 along a regional east to west cross-section line (fig. 14) indicates there is an increase in temperature with depth and also an increase in groundwater temperature toward the coast at lower depths within the Upper Floridan aquifer. At the ROMP 14 well, located in an inland recharge area, the temperature at depth increases $1^{\circ} \mathrm{F}$ per $138 \mathrm{ft}$, and at ROMP 8 well, located in a discharge area along the coast, the temperature at depth increases $1^{\circ} \mathrm{F}$ per $92 \mathrm{ft}$.

Large-scale structural variations such as increased permeability, fracture zones, or faults can enhance the thermal gradients and transmit heated waters over substantial distances (Allen and others, 2014). A permeable zone within the Avon Park Formation of the Upper Floridan aquifer, which has been identified in the ROMP well lithologic logs and in the deep oil exploration well, extends across most of the basin at a depth of about 1,100 to 1,600 ft (figs. 4, 15). Exploratory coring in the first phase of the ROMP 8 well construction extended to a depth of $1,283 \mathrm{ft}$ bls. Water temperature at the bottom of the ROMP 8 well was $94^{\circ} \mathrm{F}$, which is within the range observed at vents $\left(88-99{ }^{\circ} \mathrm{F}\right)$, indicating that the Avon Park Formation might be the source of warm water; however, given that water would be expected to cool during transit to the surface, water could be coming from deeper units. In addition to this permeable zone, Williams and Kuniansky, (2015, plate 23), identified another permeable zone within the Avon Park Formation at about 1,800 to $1,900 \mathrm{ft}$ bls. Temperature logs at deep wells, such as Stevens \#1 well and the 224B-1 well (fig. 1B; fig. 15), show a decrease in temperature along permeable zones or conduits within the Avon Park Formation, Oldsmar Formation, and the Boulder Zone, which may indicate mixing with cooler and saline waters from the Gulf of Mexico (Kohout, 1965; Kohout and others, 1977).

\section{Groundwater Geochemistry}

The groundwater geochemistry of Warm Mineral Springs was compared to Little Salt Spring, Gulf of Mexico seawater from Charlotte Harbor (USGS site number 26443508223300), and wells in the region. Little Salt Spring (USGS site number 02299480) is located about 2 miles northeast of Warm Mineral Springs (fig. $1 \mathrm{~A}$ ) and is mineralized and periodically warm; temperature records range from $72{ }^{\circ} \mathrm{F}(1960)$ to $91^{\circ} \mathrm{F}$ (1962). 
Table 3. Water-quality characteristics of samples collected at four vents at the bottom of Warm Mineral Springs, April 29, 2015 (Sarasota County, 2016b, c).

[mg/L, milligram per liter; ND, no detection; - , not applicable; $\mu \mathrm{g} / \mathrm{L}$, microgram per liter; N, nitrogen; P, phosphorus; $\mu \mathrm{S} / \mathrm{cm}$, microsiemen per centimeter]

\begin{tabular}{lcccccc}
\hline \multicolumn{1}{c}{ Parameter } & Unit & Vent A & Vent B & Vent C & Vent D & Surface \\
\hline Temperature (field) & Degrees Fahrenheit & 87 & 88 & 87 & 87 & 84.5 \\
$\mathrm{pH}$ & - & 7.14 & 7.16 & 7.20 & - & - \\
Specific conductance (field) & $\mu \mathrm{S} / \mathrm{cm}$ & 30,960 & 33,280 & 29,280 & 28,320 & 28,580 \\
Alkalinitiy & $\mathrm{mg} / \mathrm{L}$ & 128 & 124 & 113 & - & - \\
Calcium & $\mathrm{mg} / \mathrm{L}$ & 558 & 459 & 565 & 491 & - \\
Magnesium & $\mathrm{mg} / \mathrm{L}$ & 694 & 594 & 709 & 609 & - \\
Potassium & $\mathrm{mg} / \mathrm{L}$ & 214 & 186 & 220 & 182 & - \\
Sodium & $\mathrm{mg} / \mathrm{L}$ & 6,010 & 5,220 & 6,180 & 5,280 & - \\
Chloride & $\mathrm{mg} / \mathrm{L}$ & 11,131 & 11,537 & 9,143 & - & - \\
Sulfate & $\mathrm{mg} / \mathrm{L}$ & 1,624 & 1,662 & 1,322 & - & - \\
Strontium & $\mathrm{mg} / \mathrm{L}$ & 33.0 & 25.1 & 35.4 & 32.8 & - \\
Total dissolved solids & $\mathrm{mg} / \mathrm{L}$ & 20,092 & 21,120 & 16,564 & 5 & - \\
Arsenic & $\mu \mathrm{g} / \mathrm{L}$ & $\mathrm{ND}$ & $\mathrm{ND}$ & $\mathrm{ND}$ & 5 & - \\
Inorganic carbon & $\mathrm{mg} / \mathrm{L}$ & 31 & 30 & 28 & - & - \\
Ammonia nitrogen & $\mathrm{mg} / \mathrm{L}$ & 0.12 & 0.17 & 0.27 & 0.24 & - \\
Total Kjeldahl nitrogen & $\mathrm{mg} / \mathrm{L}$ & 0.46 & 0.36 & 0.51 & 0.75 & - \\
Total nitrogen & $\mathrm{mg} / \mathrm{L}$ & 1.34 & 0.40 & 0.56 & 0.80 & - \\
Nitrate nitrogen & $\mathrm{mg} / \mathrm{L}$ & 0.88 & 0.05 & 0.04 & 0.05 & - \\
Nitrite nitrogen & $\mathrm{mg} / \mathrm{L}$ & $\mathrm{ND}$ & $\mathrm{ND}$ & 0.01 & $\mathrm{~N} / \mathrm{A}$ & - \\
Nitrate + nitrite as nitrogen & $\mathrm{mg} / \mathrm{L}$ & 0.88 & 0.05 & 0.05 & 0.05 & - \\
Total phosphorus & $\mathrm{mg} / \mathrm{L}$ & 0.02 & 0.03 & 0.09 & 0.24 & - \\
\hline
\end{tabular}

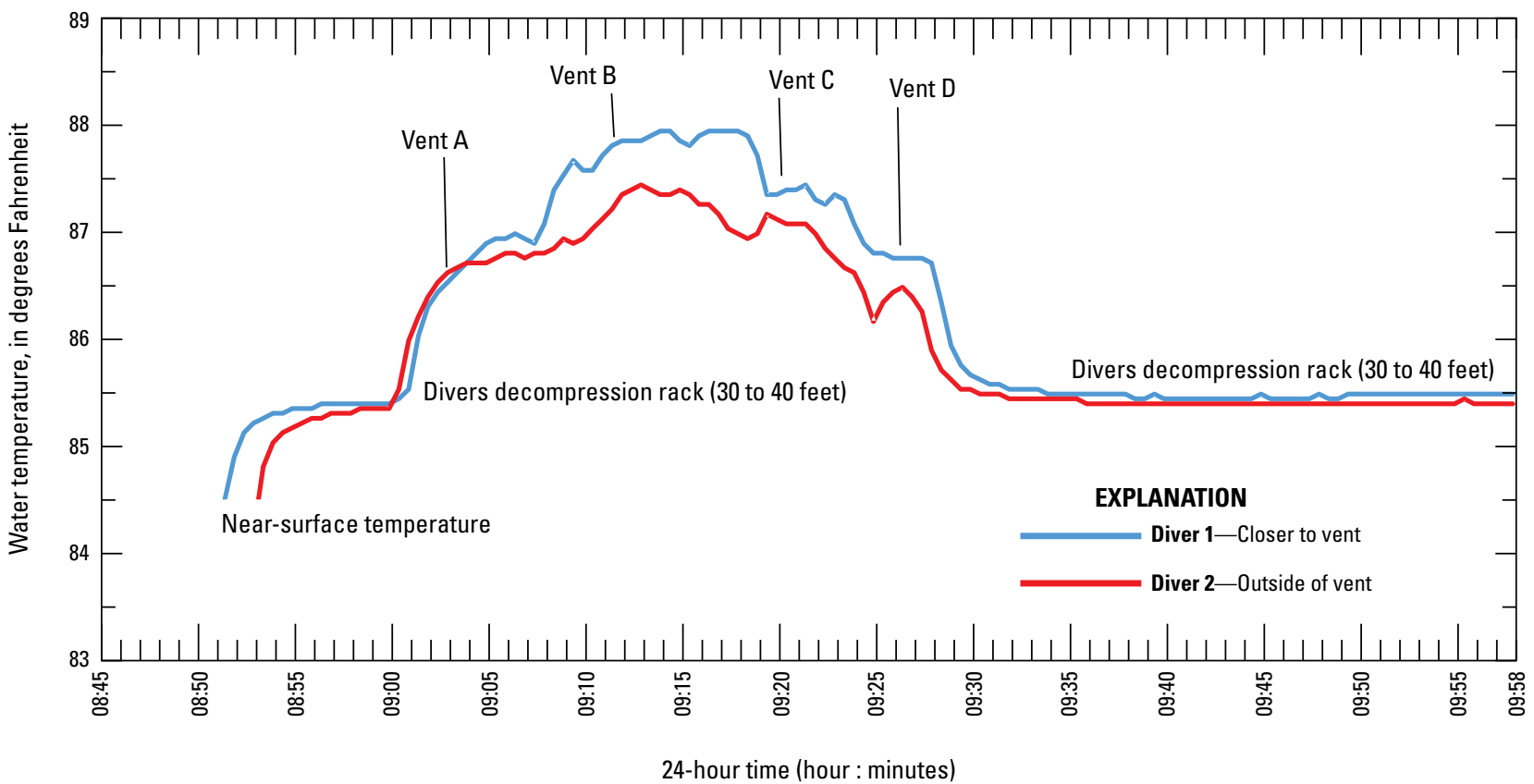

Figure 13. Time series of water temperature readings from sensors attached to divers during a sampling event on April 29, 2015. Locations of vents A-D are shown in figure 10 (Sarasota County, 2016b). 
WEST

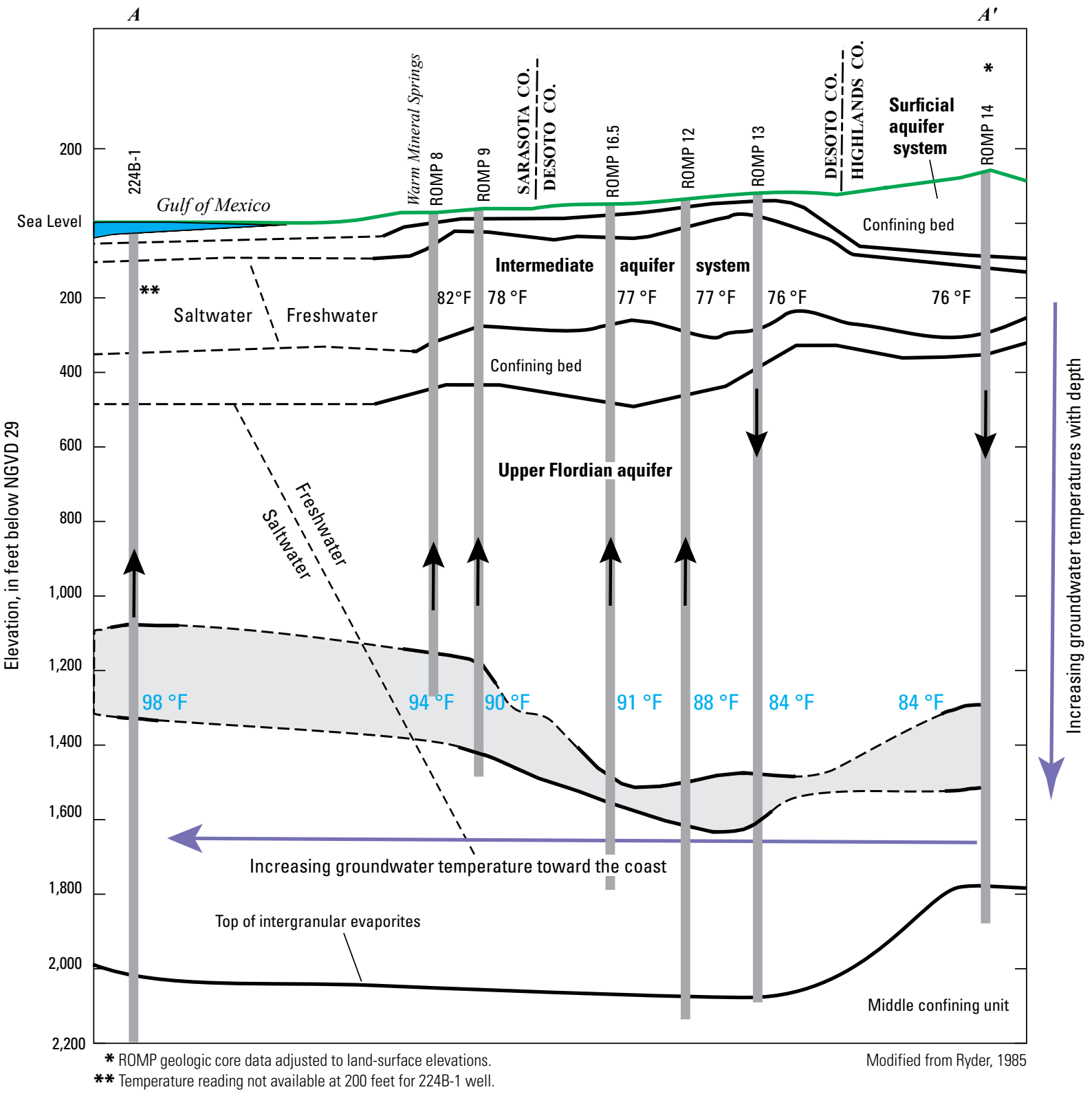

EXPLANATION

High permeability fractured dolostone within the Avon Park Formation-Dashed lines represent inferred boundary

Well in area of recharge for the Upper Floridan aquifer

Well in area of discharge for the Upper Floridan aquifer $82^{\circ} \mathrm{F}$ Comparison of groundwater temperatures for ROMP wells in the intermediate aquifer system-At 200 feet, in degrees Fahrenheit $\left({ }^{\circ} \mathrm{F}\right)$; temperature obtained from geophysical logs

$94^{\circ} \mathrm{F}$ Comparison of groundwater temperatures for ROMP wells in the Avon Park Formation within the Upper Floridan aquifer-At 1,300 feet, in degrees Fahrenheit $\left({ }^{\circ} \mathrm{F}\right)$; temperature obtained from geophysical logs

Figure 14. Cross section of hydrologic units along ROMP wells and well 224B-1, showing a pattern of increasing groundwater temperatures from Highlands to Sarasota Counties (location of cross-section line shown in figure 6). 


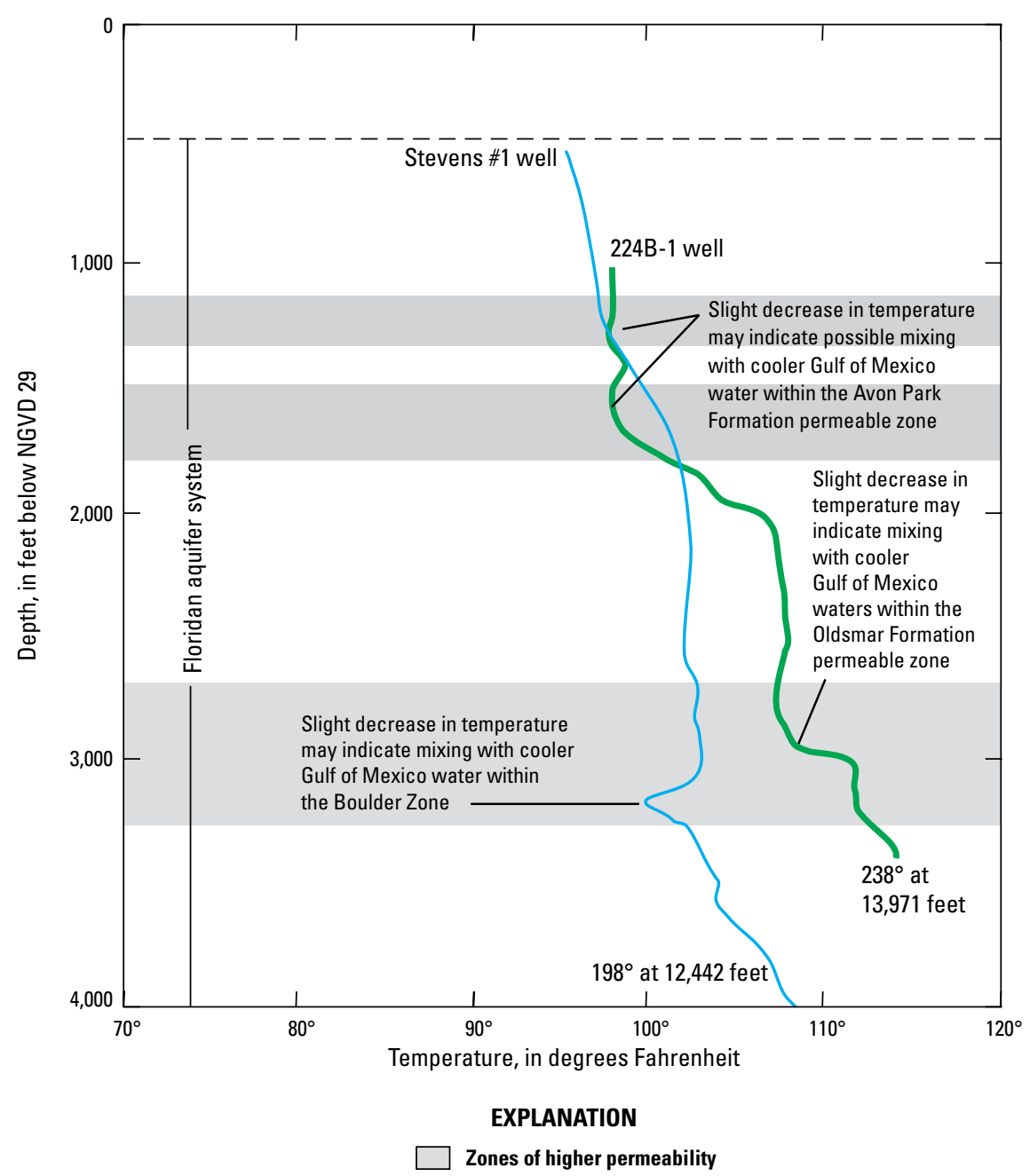

Figure 15. Geophysical temperature logs showing the possible mixing of cooler Gulf of Mexico water with groundwater from several high permeable zones within the Floridan aquifer system (location of wells shown in figure $1 B$; modified from Kohout and others, 1977; increased permeability zone adapted from Williams and Kuniansky, 2015, plate 23).

Wells in the region that were examined include the ROMP 12 and 13 wells at two levels within the Avon Park Formation: the Upper Floridan aquifer and the middle confining unit.

Geochemical analyses can be represented by a Stiff diagram or pattern (Stiff, 1951). A Stiff diagram is a graphical representation (such as a polygon) of a geochemical analysis, and the width of the diagram is an approximate indication of total ionic content (Hem, 1985, p. 175). Herein, three horizontal axes are used to represent the concentrations of cations and anions. A "T" shaped diagram indicates large concentrations of sodium-chloride in groundwater (plotted along the top-most axis). Stiff diagrams indicate that all of the sampled waters were influenced by sodium-chloride by varying degrees (fig. 16). Warm Mineral Springs and nearby Little Salt Spring differ in both sodium-chloride concentration and total ionic content, despite the proximity of these two springs. The lowest sodium-plus-potassium and chloride concentration is from water samples of Little Salt Spring. The Stiff diagram for Little Salt Spring is similar to the Stiff diagram for the ROMP 13 well, but with lower ionic content. The geochemistry of Little Salt Spring and the ROMP 13 well indicate a greater contribution from freshwater sources than at other sites examined. The ROMP 13 well is located in an area of recharge (fig. 6) to the Upper Floridan aquifer. The Stiff diagram for the bottom sample at Warm Mineral Springs is more similar to that of the ROMP 12 well Avon Park Formation sample (1,600 ft depth; Upper Floridan aquifer) than other sites examined.

Gypsum and anhydrite, which are sources of sulfate, are abundant at the base of the Upper Floridan aquifer, the middle confining unit, and the Lower Floridan aquifer (Miller, 1986). 


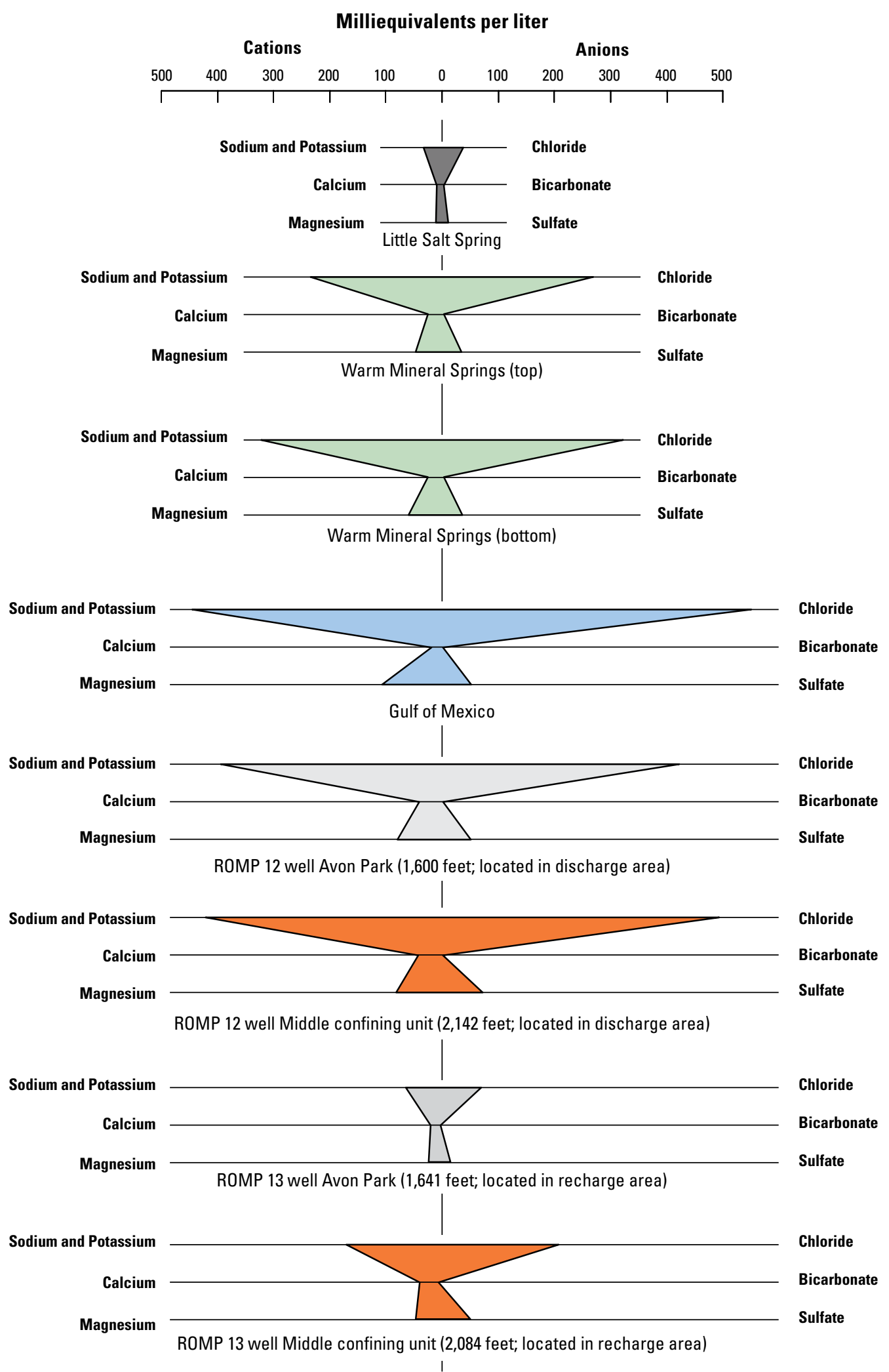

Figure 16. Stiff diagrams of water from Little Salt Spring and Warm Mineral Springs, Gulf of Mexico, and Upper Floridan aquifer and middle confining unit within the Avon Park Formation in a recharge and discharge area. 
Stiff diagrams (plotted in milliequivalents per liter) indicate that the sulfate concentration in water from Warm Mineral Springs $(1,700$ milligrams per liter $[\mathrm{mg} / \mathrm{L}])$ is more similar to groundwater from the Upper Floridan aquifer ROMP 12 well in the Avon Park Formation $(2,523 \mathrm{mg} / \mathrm{L} ; 1,600 \mathrm{ft}$ bls) rather than the more sulfate-enriched water from the middle confining unit in the Avon Park Formation $(3,500 \mathrm{mg} / \mathrm{L}$; $2,142 \mathrm{ft}$ bls). The similarity of sulfate concentrations for Warm Mineral Springs and the Upper Floridan aquifer in the Avon Park Formation indicates a deep source of water, possibly $1,600 \mathrm{ft}$ bls or deeper. Geologic logs near ROMP 9 wells indicate isolated anhydrite deposits at about 1,550 to 1,600 ft bls (Williams and Kuniansky, 2015, plate 23), which might act as a source of sulfate.

The chemistry of the wells located in the discharge area reflects a typical freshwater-saltwater coastal aquifer flow system, where less mineralized water overlies a deeper saltwater flow system (Cooper, 1959). Saline water occurs in deeper parts of the Upper Floridan aquifer (Avon Park Formation) near the Gulf Coast and below the base of the Upper Floridan aquifer in inland areas (Sacks and Tihansky, 1996). On a regional scale, the Stiff diagram for Avon Park Formation ROMP 14 and 13 wells, located in the recharge area, shows a more dilute ionic signature than ROMP 12, 16.5, and 9 wells, located in the discharge area (fig. 17). Stiff diagrams for wells in the discharge area below depths of about $1,500 \mathrm{ft}$ bls have the "T" pattern similar to the Stiff diagram for Warm Mineral Springs, indicating a source of water from 1,500 ft bls or greater, and from the Avon Park Formation or deeper units.

\section{Water Quality}

Geochemical data for Warm Mineral Springs are available from several sources, including Ferguson and others (1947), Rosenau and others (1977), Scott and others (2004), Ryan and others (2011), the USGS NWIS, the Southwest Florida Water Management Information System (Southwest Florida Water Management District, 2016a), and Sarasota County (2016a). Notable at Warm Mineral Springs are concentrations of chloride and sodium, levels of specific conductance, detection of nitrate and ammonium, and sulfate concentrations. Secondary effects on water quality include the presence of sulfur-reducing bacteria and changes in water clarity in the spring pool.

The five ions with the greatest concentrations in Warm Mineral Springs were, as listed in order of decreasing concentration: chloride, sodium, sulfate, magnesium, and calcium (table 4). The median concentrations of chloride and sodium in the spring water were about 9,500 and $5,100 \mathrm{mg} / \mathrm{L}$, respectively; whereas, concentrations of these constituents in Gulf of Mexico seawater were about 18,000 and 9,900 mg/L, respectively. Water-quality characteristics of Warm Mineral Springs were also compared with another third-magnitude, brackish-water coastal spring (Baird Creek Head Spring) and 103 other springs of varying size in Florida (Harrington and others, 2010; table 4). Warm Mineral Springs had the highest temperature and the greatest mineralized content (relative to the five constituent ions listed above) in comparison to these other springs, indicating a deeper source of water for Warm Mineral Springs than for Baird Creek Head Spring and the other 103 springs compiled by Harrington and others (2010).

Specific conductance can be used as a measure of salinity and water quality. On April 29, 2015, divers collected water samples from four out of the five major bottom vents (A-D, fig. 10A, $B$ ), and physical properties, major ions, and nutrients (Sarasota County, 2016c) were evaluated. The specific conductance varied slightly among the four vents sampled, and values ranged from 28,320 microsiemens per centimeter $(\mu \mathrm{S} / \mathrm{cm})$ at 25 degrees Celsius at vent $\mathrm{D}$ to $33,280 \mu \mathrm{S} / \mathrm{cm}$ at vent $\mathrm{B}$ (table 3). For comparison, the specific conductance of seawater is on the order of 50,000 $\mu \mathrm{S} / \mathrm{cm}$ (Gulf of Mexico, USGS site number 264435082233000). Specific conductance measurements of the Upper Floridan aquifer (Avon Park permeable zone; 1,269-1,283 feet bls) for the ROMP 8 well was $9,930 \mu \mathrm{S} / \mathrm{cm}$ (Clayton, 2010). This finding indicates that groundwater was derived from a source deeper than about 1,300 ft bls. Specific conductance at the ROMP 9 well, sampled at a depth of about $1,500 \mathrm{ft}$ bls in the Avon Park Formation of the Upper Floridan aquifer, had a specific conductance that was $38,240 \mu \mathrm{S} / \mathrm{cm}$ and the temperature was $90^{\circ} \mathrm{F}$ (Thompson, 1997). This finding indicates that aquifers at a depth of about $1,500 \mathrm{ft}$ or greater might be a source of groundwater to the spring bottom vents. The specific conductance is lower at the surface of the Warm Mineral Springs pool $(28,580 \mu \mathrm{S} / \mathrm{cm})$ than at depth, which indicates the input of fresher groundwater from the shallower aquifers above the spring vents. The lateral input of groundwater from the upper part of the sink probably varies on the basis of wet or dry season. Continuous water-quality monitoring of specific conductance would provide information on the variations in dilution of Warm Mineral Springs by surface water.

Nitrate-nitrogen (nitrate, $\mathrm{NO}_{3}$ ) is the principal chemical indicator for nutrient enrichment of Florida springs (Harrington and others, 2010). Nitrate concentrations were less than $0.2 \mathrm{mg} / \mathrm{L}$ for most Florida springs prior to the $1970 \mathrm{~s}$, but recently concentrations exceeding $1 \mathrm{mg} / \mathrm{L}$ have been measured in many springs (Harrington and others, 2010). The drinking water standard for nitrate adopted by the U.S. Environmental Protection Agency is $10 \mathrm{mg} / \mathrm{L}$, measured as nitrogen (U.S. Environmental Protection Agency, 2016). Water samples collected at the surface at Warm Mineral Springs had a low median nitrate concentration of $0.01 \mathrm{mg} / \mathrm{L}$ (Ryan and others, 2011); nitrate samples collected at the spring vents on April 29, 2015, had concentrations of $0.04-0.05 \mathrm{mg} / \mathrm{L}$ for vents $\mathrm{B}, \mathrm{C}$, and $\mathrm{D}$ and $0.88 \mathrm{mg} / \mathrm{L}$ at vent $\mathrm{A}$ (table 3). Most of the groundwater discharge comes out of vent $\mathrm{B}$ with much smaller amounts of discharge out of vent $A$. The higher nitrate concentration from vent A indicates the variability of the source water between the adjoining vents. Additional monitoring is needed to determine trends or persistence of detection of nitrate at Warm Mineral Springs. 


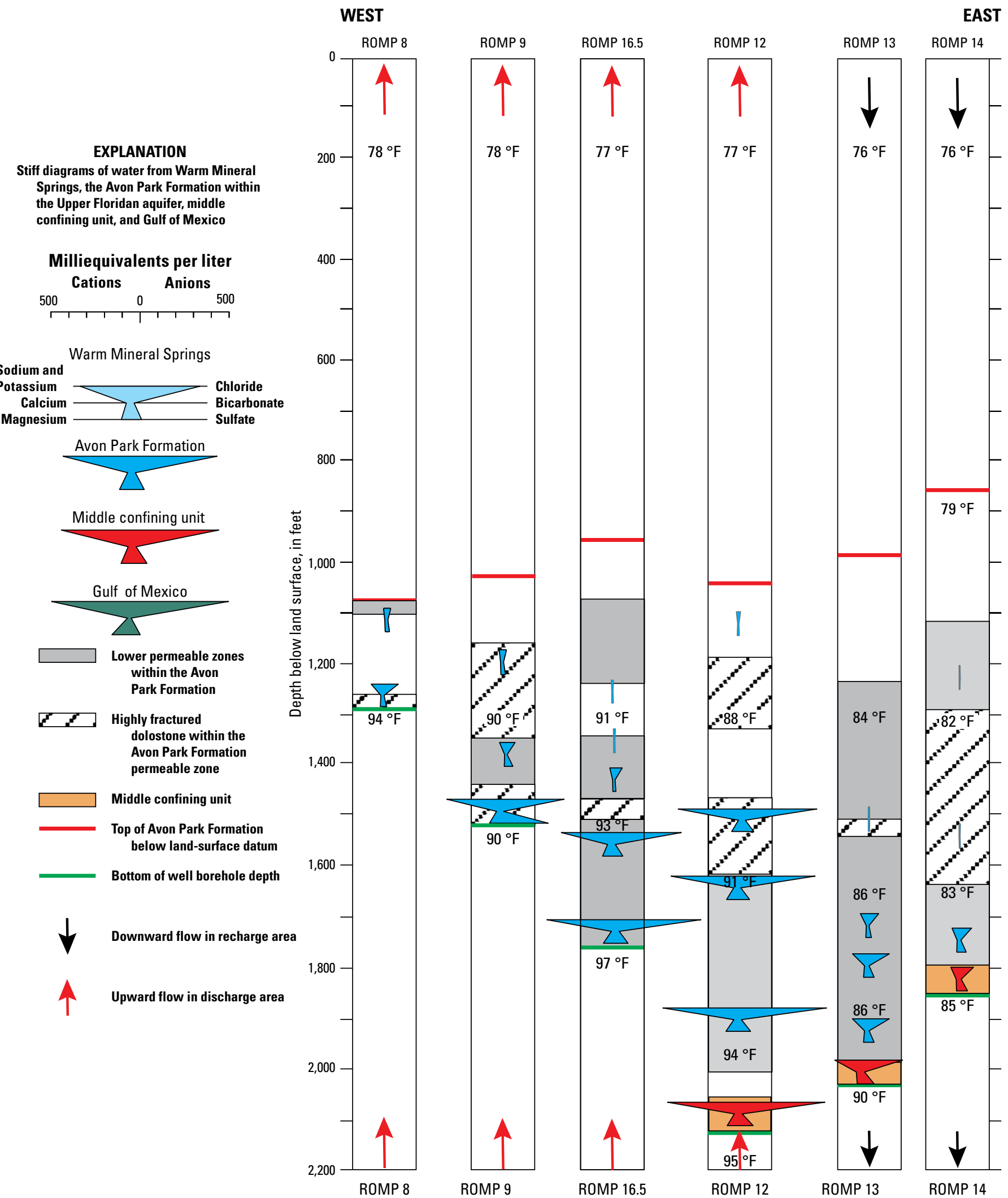

Figure 17. Comparison of water quality, temperature with depth, and flow directions within the Avon Park Formation of the Upper Floridan aquifer and the underlying middle confining unit. 
Table 4. Median values of water-quality data collected at Warm Mineral Springs, Baird Creek Head Spring (also a coastal spring), and numerous west-central Florida springs and the Gulf of Mexico.

[mg/L, milligram per liter; PCU, platinum cobalt unit; $\mathrm{ft}^{3} / \mathrm{s}$, cubic foot per second; $\mathrm{N}$, nitrogen; $\mathrm{P}$, phosphorus; $\mu \mathrm{S} / \mathrm{cm}$, microsiemen per centimeter; NTU, nephelometric turbidity unit; ${ }^{\circ} \mathrm{F}$, degrees Fahrenheit; <, less than; >, greater than; —, missing or not applicable]

\begin{tabular}{|c|c|c|c|c|}
\hline Parameter & $\begin{array}{l}\text { Warm Mineral } \\
\text { Springs } \\
\text { water-quality } \\
\text { characteristics } \\
\text { (median) }^{1}\end{array}$ & $\begin{array}{l}\text { Baird Creek Head } \\
\text { Spring near } \\
\text { Chassahowitzka } \\
\text { water-quality } \\
\text { characteristics }^{2}\end{array}$ & $\begin{array}{c}\text { West-central } \\
\text { Florida spring } \\
\text { water-quality } \\
\text { characteristics } \\
\text { (median) }^{3}\end{array}$ & $\begin{array}{c}\text { Gulf of Mexico } \\
\text { near Charlotte } \\
\text { Harbor }^{4}\end{array}$ \\
\hline Alkalinity (mg/L) & 132 & 143 & 115 & 121 \\
\hline Calcium (mg/L) & 488 & 110 & 56 & 360 \\
\hline Chloride (mg/L) & 9,470 & 2,750 & 21 & 18,000 \\
\hline Color, (PCU) & 5 & - & 0 & 5 \\
\hline Discharge $\left(\mathrm{ft}^{3} / \mathrm{s}\right)$ & 8.3 & 6.2 & $<1$ to $>100$ & - \\
\hline Dissolved oxygen $(\mathrm{mg} / \mathrm{L})$ & 1.2 & 3.3 & 3 & 7.8 \\
\hline Magnesium (mg/L) & 580 & 185 & 7.6 & 1,200 \\
\hline Nitrate + nitrite $(\mathrm{N})(\mathrm{mg} / \mathrm{L})$ & 0.01 & 0.21 & 0.48 & 0.02 \\
\hline Nitrogen, ammonia $(\mathrm{N})(\mathrm{mg} / \mathrm{L})$ & 0.35 & - & 0.01 & 0.06 \\
\hline $\mathrm{pH}$ & 7.2 & 7.6 & 7.6 & 7.8 \\
\hline Phosphorous, (P) (mg/L) & 0.15 & 0.02 & 0.04 & 0.03 \\
\hline Potassium (mg/L) & 179 & 22 & 1.2 & 440 \\
\hline Sodium $(\mathrm{mg} / \mathrm{L})$ & 5,140 & 20 & 11 & 9,900 \\
\hline Silica $(\mathrm{mg} / \mathrm{L})$ & 17 & 8 & 9 & 0.7 \\
\hline Specific conductance $(\mu \mathrm{S} / \mathrm{cm})$ & 27,898 & 8,480 & 374 & 43,900 \\
\hline Sulfate $(\mathrm{mg} / \mathrm{L})$ & 1,645 & 395 & 16 & 2,400 \\
\hline Total organic carbon $(\mathrm{mg} / \mathrm{L})$ & 2.2 & - & 0.82 & - \\
\hline Total dissolved solids (mg/L) & 17,845 & - & 228 & 32,400 \\
\hline Turbidity (NTU) & 2 & - & 0.3 & 0.2 \\
\hline Surface-water temperature $\left({ }^{\circ} \mathrm{F}\right)$ & 84.5 & 74 & 72 & 84 \\
\hline
\end{tabular}

${ }^{1}$ Median values from data by Scott and others (2004), Sarasota County (2016a), Southwest Florida Water Management District (2016b), U.S. Geological Survey (USGS site numbers 02299260 and 270333082154000); discharge from August 11, 2014, at USGS site number 02299260; water temperature and specific conductance measured by divers on April 29, 2015.

${ }^{2}$ USGS database site number 284230082344000 Baird Creek Head Spring near Chassahowitzka, November 15, 1988.

${ }^{3}$ Median values based on 33 to 103 water-quality observations for various springs in west-central Florida (Harrington and others, 2010).

${ }^{4}$ USGS database site number 26443508223300 Charlotte Harbor sample site CH15 Gulf of Mexico, September 21, 1983.

Ammonia-nitrogen was reported in water samples collected at the pool surface of Warm Mineral Springs (table 3). Ammonia-nitrogen is seldom detected in spring water because of its tendency to degrade rapidly to other nitrogen forms; however, when detected, it can be an indicator of sources of potential contamination (Harrington and others, 2010). Although ammonia-nitrogen concentrations are not considered high, they may indicate that the groundwater source for the spring was affected by human activities or a reduction of nitrate to ammonium ions (Cheng and others, 1997). Additional monitoring is needed to determine trends or persistence of ammonia-nitrogen at Warm Mineral Springs.
Sulfate concentrations are relatively high (median value of $1,750 \mathrm{mg} / \mathrm{L}$; Ryan and others, 2011) in Warm Mineral Springs compared to west-central Florida springs (median values as high as $400 \mathrm{mg} / \mathrm{L}$; Harrington and others, 2010) and are more similar to sulfate concentration for the Gulf of Mexico (USGS site number 264435082233000), which ranged from 2,400 to $2,700 \mathrm{mg} / \mathrm{L}$ (table 4 ). With the relatively high sulfate concentrations in the spring, sulfur-reducing bacteria are prevalent in the spring. Sulfur-reducing bacteria, which can live in the low-oxygen environment of the spring, can reduce natural sulfates into hydrogen sulfide (Sacks and Tihansky, 1996). The combination of natural sources of dissolved 
sulfur and low dissolved oxygen concentrations facilitates the growth of the sulfur-reducing bacteria colonies (Tuttle and Molyneaux, 1975), which flourish on the upper walls of Warm Mineral Springs (fig. 18A). Sulfur-reducing bacteria colonies are thought to contribute to the low clarity of Warm Mineral Springs (F.A. Kohout, U.S. Geological Survey, oral commun., 1976), but further research is needed to verify this assumption. The green algal mat that coats the upper walls is thought to contribute to the slight green color in the water (fig. 18B).

The water clarity at Warm Mineral Springs varies considerably. Rosenau and others (1977) discuss "cloudiness" in the spring water that begins at sunrise and becomes progressively worse as the day continues, and improves at night. There are several theories that pertain to the "cloudiness," which include the presence of sulfur-reducing bacteria that is activated in the oxygen-poor and hydrogen-sulfide rich environment, the amount of daily sunlight that activates the growth of algae and other microorganisms to form, and the stirring of sediments by bathers (Rosenau and others 1977). The cloudiness of the entire spring water column can decrease substantially after heavy and extended periods of rainfall, and the resulting clarity can persist for up to a week before the cloudiness returns (Rosenau and others 1977).

A Secchi depth reading of about $30 \mathrm{ft}$ was taken during the morning of September 14, 2011 (Ryan and others, 2011), although the clarity appeared to have declined during the day. During July 15-31, 2015, rainfall accumulation at the ROMP 8 Warm Mineral Springs rain gage was almost 12 inches, and during that time the clarity of the spring increased substantially to greater than $154 \mathrm{ft}$ (extent of the exploratory dive was $154 \mathrm{ft}$ ). Comparisons of the spring clarity are shown in the photographs taken on April 29, 2015 (fig. 19A) and July 29, 2015 (fig. 19B). Frequent Secchi depth readings would better define the trends in water clarity and continuous water-quality monitoring, especially during high rainfall events with extended periods of cloud coverage, would verify the reasons for the increase in water clarity.

\section{Discussion}

Analyses of existing data provide insights into the hydrologic processes affecting Warm Mineral Springs; however, existing data for Warm Mineral Springs were discontinuous and sparse, and outliers were detected. Confidence in data and trends would be improved if continuous hydrologic data were available at Warm Mineral Springs. Continuous monitoring would ideally monitor hydrologic variables, such as discharge and temperature, at a daily or finer time step. A more comprehensive study of Warm Mineral Springs could include continuous monitoring of hydrologic characteristics of the spring and the outlet over a period of several years. Continuous monitoring at the outlet could include discharge, while continuous monitoring in the spring could include water temperature and water-quality indicators such as specific conductance, nitrate, and turbidity (water clarity). Continuous water-quality monitoring could include measurements at each vent and at multiple depths in the spring. Periodic sampling, such as monthly sampling, of water from the different levels in the pool could be analyzed for additional constituents such as major ions and anthropogenic compounds. Sources of groundwater could be further examined using isotopic tracers. For example, concentration of isotopes of strontium in water samples could be compared to strontium concentrations measured in Cenozoic-age carbonate rocks in Florida. Isotopic tracers have by used to estimate sources of groundwater by Katz and Bullen (1996), Sacks and Tihansky (1996), Katz and others (1997, 2007), Phelps (2001), and Tihansky (2005).

Continuous monitoring data could be used to calibrate models of the response and sensitivity of Warm Mineral Springs to regional factors, such as water levels of aquifers, precipitation, and evapotranspiration. For example, Impulse Response Functions (IRFs) have been used successfully to model karst aquifer systems (Long, 2015). Discharge (response) could be modeled using water levels of several aquifers, simultaneously (impulses). A strength of models, such as IRFs, is that historical data for the impulse (such as aquifer levels) could be used to back-cast the response, such as discharge, and fill in data gaps. Examples of applications of IRFs for springs in karst settings include Long and Mahler (2013) and Stamm and others (2015). Models that estimate the sensitivity of discharge and temperature to external affects (such as weather and aquifer levels), and mixing models might prove as a valuable tool for managing the response of Warm Mineral Springs to projected changes in climate, aquifer levels, and water use.

\section{Summary}

Warm Mineral Springs, located in southern Sarasota County, is a warm ( 85 degrees Fahrenheit $\left[{ }^{\circ} \mathrm{F}\right]$ ), mineralized spring in Florida. Since 1946, a bathing spa has been in operation at Warm Mineral Springs, attracting vacationers and health enthusiasts. In addition, the warm water from the spring attracts manatees to the adjoining spring run during the winter months, which provides a vital thermal refuge for these mammals as well as an opportunity for environmental education. Archaeological evidence indicates that the spring has long been an attraction for humans. Well-preserved, late Pleistocene- to early Holocene-age human and animal bones, artifacts, and plant remains have been found in and around the spring, which adds to the unique characteristics of the spring. The spring is a multiuse resource of hydrologic importance, ecological and archaeological significance, and economic value to the community.

The circular shape and depth of Warm Mineral Springs indicate the spring formed as a large sinkhole that developed in the sand, clay, dolomite, and limestone of the Arcadia Formation of the intermediate aquifer system. The pool of Warm Mineral Springs measures about 240 feet ( $\mathrm{ft}$ ) in diameter at the surface and has a maximum depth of about $205 \mathrm{ft}$. A debris 


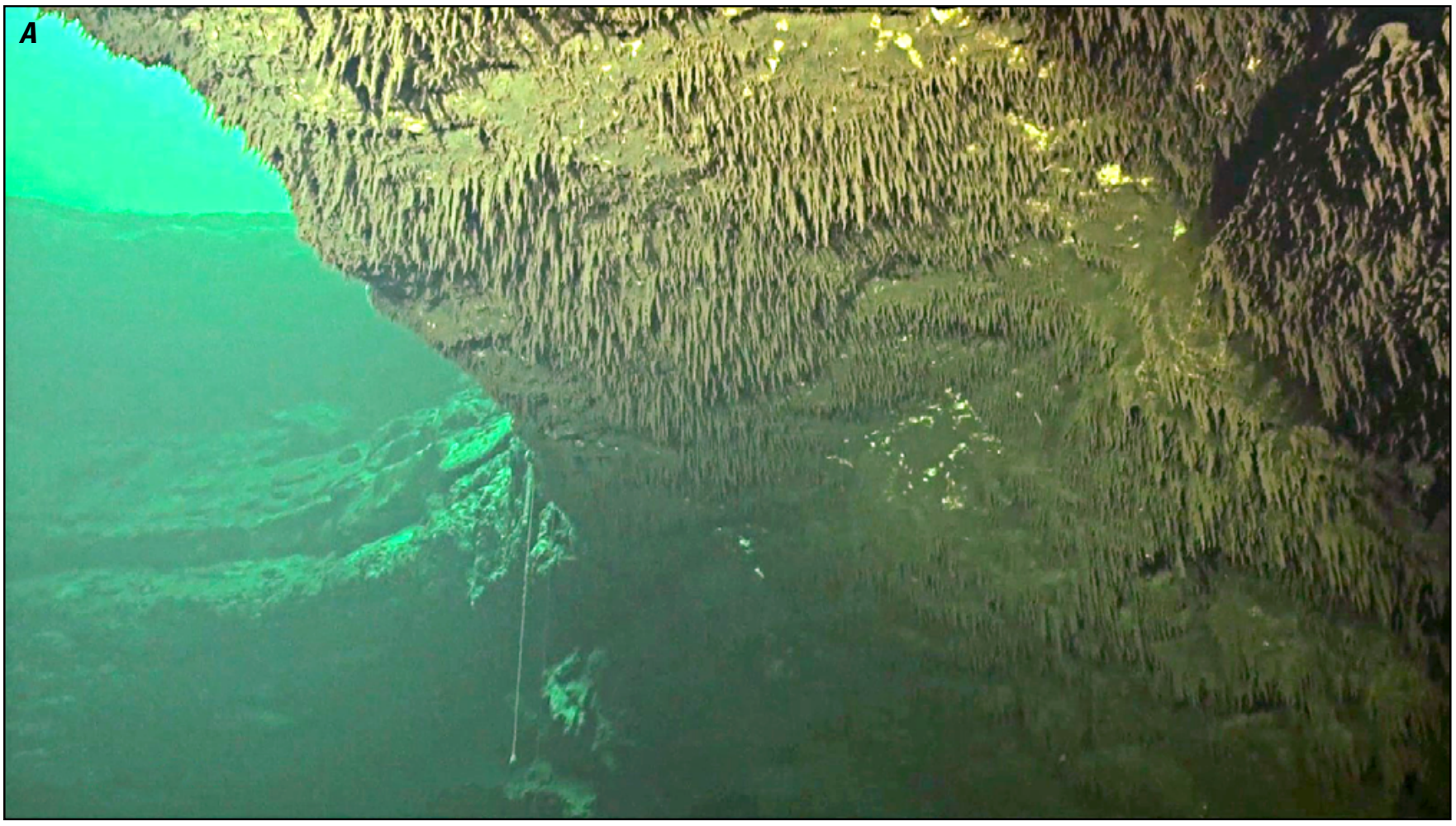

Photograph by Curt Bowen, ADM Exploration Foundation, 2015

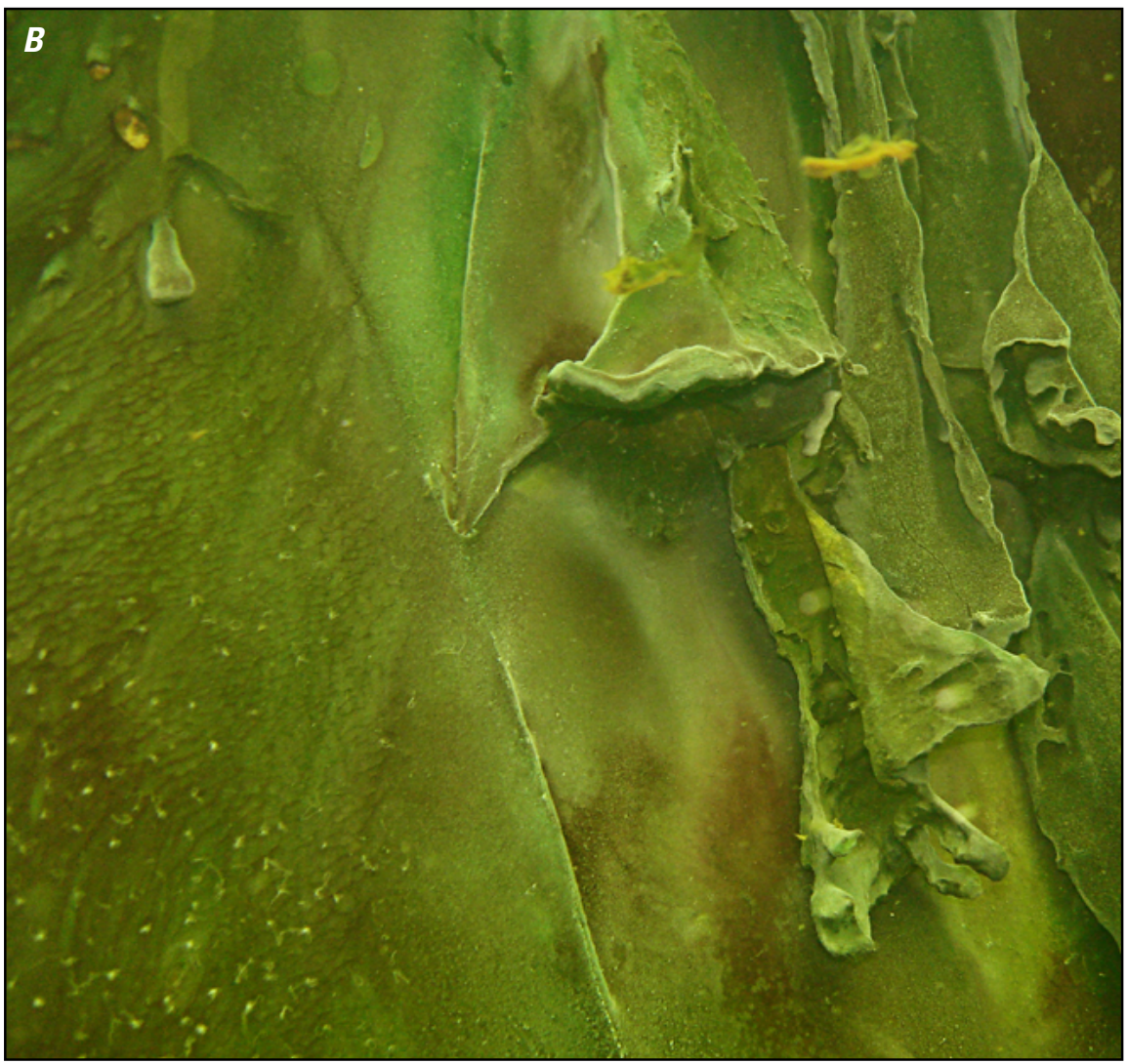

Photograph by Rene Jannemann, Sarasota County, 2015

Figure 18. Photographs showing $A$, sulfur-reducing bacteria and $B$, green algae that coat the walls of Warm Mineral Springs. 


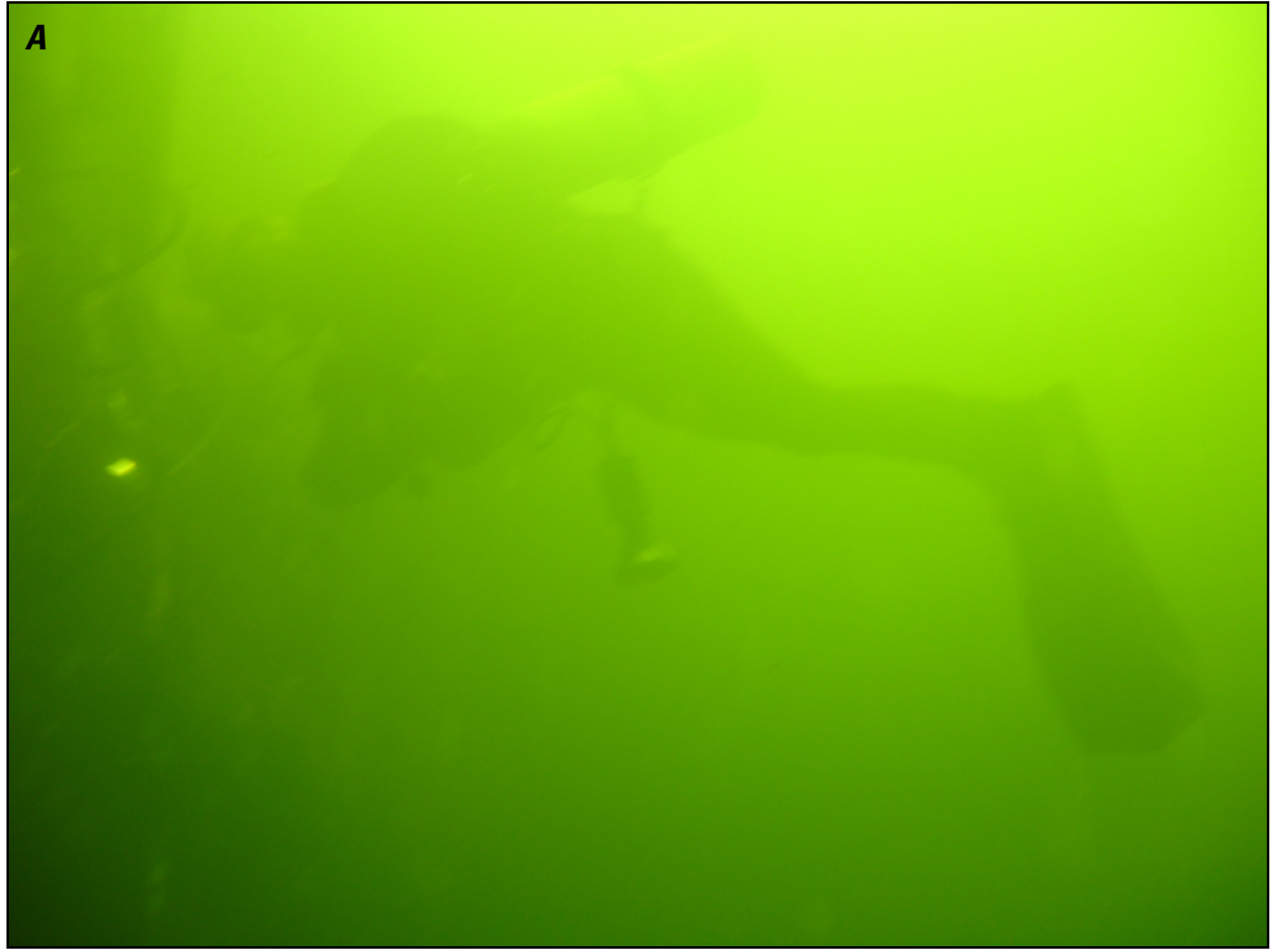

Photograph by Rene Jannemann, Sarasota County, 2015

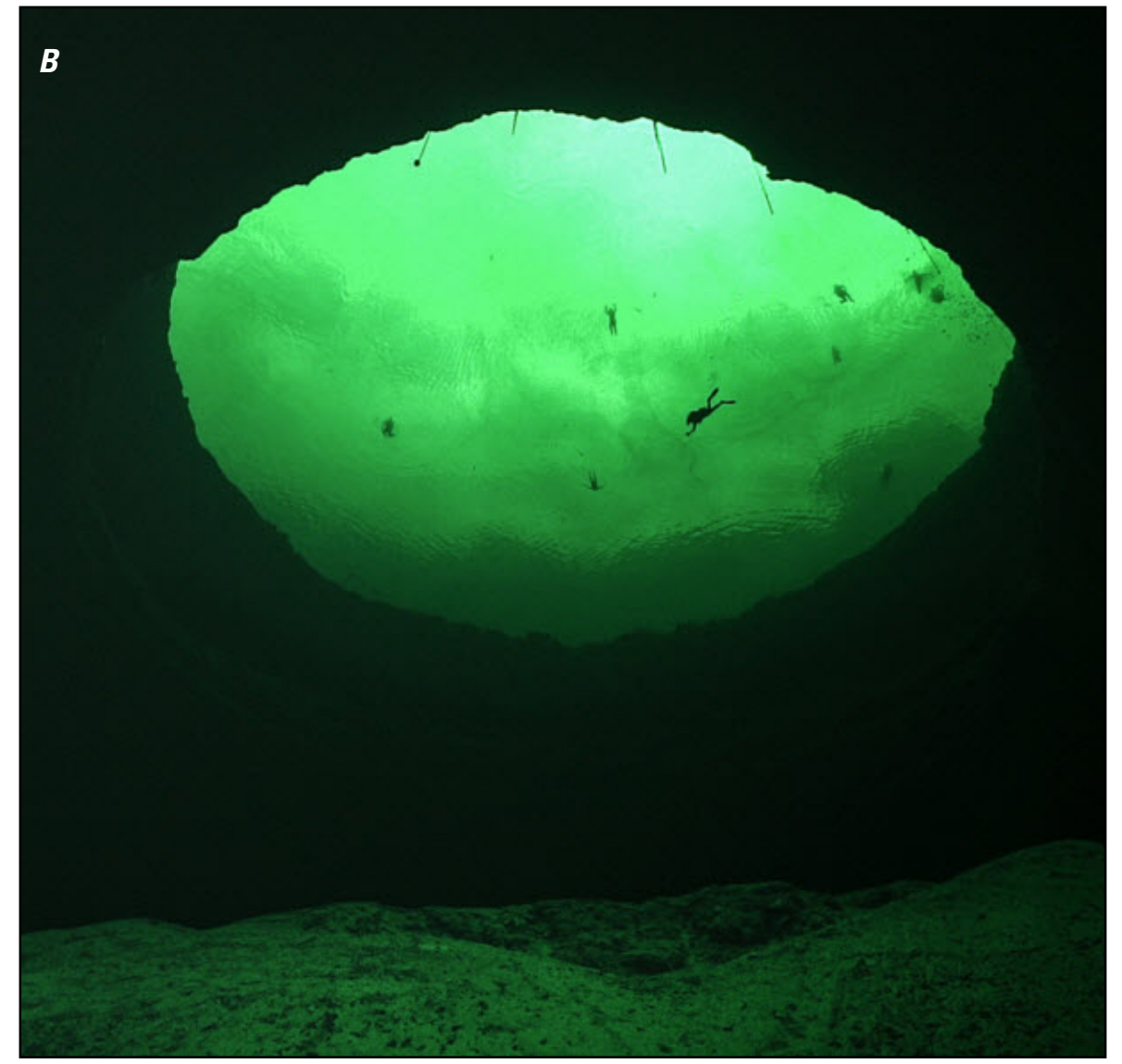

Photograph by Curt Bowen, ADM Exploration Foundation, 2015

Figure 19. Photographs showing Warm Mineral Springs water clarity at $A, 40$ feet below the spring surface during a dry period (April 29, 2015) and at $B, 154$ feet after an extended period of rain (July 29, 2015). 
cone, which measures about $225 \mathrm{ft}$ wide and $125 \mathrm{ft}$ thick, covers much of the bottom of Warm Mineral Springs and was formed from the collapse of material at the surface. Late Pleistocene-age water levels were about $100 \mathrm{ft}$ (30 meters) below the modern spring pool surface at about $12 \mathrm{ka}$, estimated on the basis of plant material and radiometric dating of human remains in the sink; this indicates that the sinkhole formed before $12 \mathrm{ka}$.

The geologic formations exposed at Warm Mineral Springs consist of the late Oligocene-age to Miocene-age Arcadia Formation of the Hawthorn Group. The Hawthorn Group is composed of carbonate rocks with sand and clay layers. Underlying the Hawthorn Group are Oligocene-age to Eocene-age limestone and dolostone, including the Suwannee Limestone, Ocala Limestone, and Avon Park Formation. Three aquifers are described in the region of Warm Mineral Springs: the surficial aquifer system, the intermediate aquifer system within the Hawthorn Group, and the Upper Floridan aquifer in the Suwannee Limestone, Ocala Limestone, and Avon Park Formation. The Hawthorn Group also acts as an upper confining unit to the Upper Floridan aquifer.

Groundwater flow paths inferred from the configuration of the potentiometric surface of the Upper Floridan aquifer for September 2010 are generally from areas of recharge (in Polk and Highlands Counties) to areas of discharge (in Manatee, Sarasota, DeSoto, and Charlotte Counties). Warm Mineral Springs is located in an area with the potential for discharge to the surface. Groundwater flow models indicate that downward flow into the Upper Floridan aquifer occurs in inland areas, and upward flow toward the surface occurs in coastal areas, such as at Warm Mineral Springs.

Declines in groundwater levels occurred in the Southern West-Central Florida Groundwater Basin from the 1930s to the 1970s as a result of water withdrawals for phosphate mining and other uses. The historical increase in groundwater withdrawals, and other factors such as weather conditions and agricultural conservation, resulted in a 10 - to 20 - $\mathrm{ft}$ regional decline in the potentiometric surface of the Upper Floridan aquifer by May 1975 relative to predevelopment levels; the water level remained at approximately that same level in May 2007 in the area of Warm Mineral Springs.

Warm Mineral Springs is a third-magnitude spring, which is defined by a mean discharge of less than 10 cubic feet per second $\left(\mathrm{ft}^{3} / \mathrm{s}\right)$. Discharge at Warm Mineral Springs decreased from about $11-12 \mathrm{ft}^{3} / \mathrm{s}$ in the $1940 \mathrm{~s}$ to about $6-9 \mathrm{ft}^{3} / \mathrm{s}$ in the 1970 s, and remained at about that level for the remainder of the period of record. This pattern of decrease until about the 1970s is consistent with the trend of water withdrawals and changes in the potentiometric surface of the Upper Floridan aquifer in the region. This finding indicates that basin-scale changes to the groundwater system have affected discharge at Warm Mineral Springs. Similarity of changes in regional water use and discharge at Warm Mineral Springs indicates that basin-scale changes to the groundwater system have affected discharge at Warm Mineral Springs. No significant trend in water temperature was found over the period of record, 1943-2015.
Multiple lines of evidence, including Stiff diagrams of groundwater geochemistry and groundwater temperature, were used to estimate the sources of groundwater that discharges from Warm Mineral Springs. The Avon Park Formation within the Upper Floridan aquifer at a depth of about 1,400 to $1,600 \mathrm{ft}$, or deeper, is a likely source of warm and mineralized groundwater. There are five known warm water vents or solution conduits at the bottom of the spring. Specific conductance at Warm Mineral Springs was high, and ranged from 28,320 to 33,280 microsiemens per centimeter $(\mu \mathrm{S} / \mathrm{cm})$ at bottom vents. The specific conductance was approximately half of that typical for saltwater. Specific conductance at the nearby ROMP 8 well was $9,930 \mu \mathrm{S} / \mathrm{cm}$ at a depth of $1,269-1,283 \mathrm{ft}$ below land surface (bls), indicating that groundwater at Warm Mineral Springs was sourced from more than 1,300 ft bls. Specific conductance of groundwater from the ROMP 9 well at a depth of 1,500 ft bls was similar to that of Warm Mineral Springs. The median concentration of chloride and sodium in the spring water was about 9,500 and 5,100 milligrams per liter ( $\mathrm{mg} / \mathrm{L})$, respectively. For comparison, concentration of these constituents in Gulf of Mexico seawater was about 18,000 and $9,900 \mathrm{mg} / \mathrm{L}$, respectively. Water-quality characteristics of Warm Mineral Springs were compared with other springs of varying size in Florida; Warm Mineral Springs had the highest temperature and the greatest mineralized content. This finding might reflect a deeper source of water at Warm Mineral Springs than at other springs in the region.

Analysis of water-quality samples collected from Warm Mineral Springs detected ammonium-nitrogen and nitrates, but at low concentrations. The drinking water standard adopted by the U.S. Environmental Protection Agency is $10 \mathrm{mg} / \mathrm{L}$ nitrate, measured as nitrogen. Water samples collected at the surface at Warm Mineral Springs had a low median nitrate concentration of $0.01 \mathrm{mg} / \mathrm{L}$. Water samples collected at the bottom spring vents by divers on April 29, 2015, had concentrations of $0.9 \mathrm{mg} / \mathrm{L}$ nitrate-nitrogen at vent $\mathrm{A}$ and $0.04-0.05 \mathrm{mg} / \mathrm{L}$ at vents $\mathrm{B}, \mathrm{C}$, and D. Spring water is characterized by a slightgreen color, with varying water clarity, low dissolved oxygen (indicative of deep groundwater), and a hydrogen sulfide odor. Typically the water clarity is highest in the morning (about $30 \mathrm{ft}$ Secchi depth) and often decreases throughout the day.

Analyses of existing data provide insight into the hydrologic processes affecting Warm Mineral Springs; however, data have been sparsely and discontinuously collected since the 1940s. Continuous monitoring of hydrologic characteristics such as discharge, temperature, specific conductance, and water-quality indicators such as nitrate and turbidity (water clarity) sensors, would be valuable for monitoring. Continuous data could be used for modeling and analyses of the sensitivity of the spring to external forcings. Models could include Impulse Response Functions, which have been used successfully in karst aquifer systems. Water samples could also be analyzed for isotopic ratios of tracers, such as strontium. Isotopic ratios and concentrations could be used to identify the subsurface source(s) of water discharging from Warm Mineral Springs through the development of mixing models. 


\section{References Cited}

Allen, D.M., Bayer, P., Ferguson, G., and Blum, P., 2014, Preface-Hydrogeology of shallow thermal systems: Hydrogeology Journal, v. 22, no. 1, p. 1-6.

Baldini, S.M., 1998, ROMP 13 Tippen Bay monitor well site DeSoto County, Florida-Phase two exploratory drilling and monitor well construction: Brooksville, Fla., Southwest Florida Water Management District, 129 p.

Basso, R., and Schultz, R., 2003, Long-term variation in rainfall and its effect on Peace River flow in west-central Florida: Brooksville, Fla., Southwest Florida Water Management District, Hydrologic Evaluation Section, 39 p.

Bowen, C., 1996, Warm Mineral Springs survey project: Deeptech, issue 6, p. 24-31. [Also available at http://www. warmmineral.com/wms/wmspdf/Bowen,C1996-R.pdf.]

Bowen, C., 2015, Warm Mineral Springs, diagram of springbottom outline and spring vents, accessed August 19, 2015, at http://www.warmmineral.com/wms/wmssurvey.html.

Cheng, I. F., Muftikian, R., Fernando, Q., and Korte, N., 1997, Reduction of nitrate to ammonia by zero-valent iron: Chemosphere, v. 35, no. 11, p. 2689-2695.

Clausen, C.J., Brooks, H.K., and Wesolowsky, A.B., 1975, The early man site at warm Mineral Springs, Florida: Journal of Field Archaeology, v. 2, no. 3, p. 191-213.

Clayton, J.M., 1998, ROMP 14 Hicoria, Final report-Drilling and testing program, Highlands Ridge water resource assessment project, Highlands County, Florida: Brooksville, Fla., Southwest Florida Water Management District, 375 p.

Clayton, J.M., 1999, ROMP 12, Prairie Creek, Final reportDrilling and testing program, Southern District waterresources assessment project, DeSoto County, Florida: Brooksville, Fla., Southwest Florida Water Management District, 403 p.

Clayton, J.M., 2010, Hydrogeology and well construction at the ROMP 8-Warm Mineral Springs well site in North Port, Sarasota County, Florida: Southwest Florida Water Management District, $171 \mathrm{p}$.

Cockrell, W.A., 1975, Warm Mineral Springs, 1975-A multidisciplinary approach to a 10,000 BP archaeological site [abs.]: Florida Scientist, v. 38, supplement 1, p. 19.

Cockrell, W.A., 1988, Current status of the Warm Mineral Springs archaeological research project: 1987, in Delgado, J.P, ed., Underwater Archaeology Proceedings from the Society for Historical Archaeology Conference, Reno, Nev.: Society for Historical Archaeology, 10 p.
Cockrell, WA., 1990, Archaeological research at Warm Mineral Springs, Florida, in Jaap, W.C., ed., Diving for Science... 1990: University of South Florida, St. Petersburg, Florida, Proceedings of the American Academy of Underwater Sciences Tenth Annual Scientific Diving Symposium, October 4-7, 1990, p. 69-78. [Also available at http://archive.rubicon-foundation.org/xmlui/bitstream/ handle/123456789/9533/AAUS_1990_7.pdf?sequence=1.]

Cooper, H.H., 1959, A hypothesis concerning the dynamic balance of fresh water and salt water in a coastal aquifer: Journal of Geophysical Research, v. 64, no. 4, p. 461-467.

Copeland, R., 2003, Florida spring classification system and spring glossary: Florida Geological Survey Special Publication No. 52, 17 p. [Also available at http://www.dep.state. fl.us/geology/geologictopics/springs/sp_52.pdf.]

Cunningham, K.J., 2013, Integrating seismic-reflection and sequence-stratigraphic methods to characterize the hydrogeology of the Floridan aquifer system in southeast Florida: U.S. Geological Survey Open-File Report 2013-1181, 8 p.

Darton, N.H., 1920, Geothermal data of the United States, including many original determinations of underground temperature: U.S. Geological Survey Bulletin 701, 95 p.

DeWitt, D.J., and Mallams, J.L., 2007, The Hawthorn aquifer system-A proposal for hydrostratigraphic nomenclature revision in southwest Florida: Geological Society of America Abstracts with Programs, v. 39, no. 2, p. 89.

Ferguson, G.E., Lingham, C.W., Love, S.K., and Vernon, R.O., 1947, Springs of Florida: Florida Geological Survey, Bulletin 31, 198 p.

Fetter, C.W., 2001, Applied hydrogeology (4th ed.): Upper Saddle River, New Jersey, Prentice Hall, 598 p.

Gates, M.T., 2001, Hydrogeology of the ROMP 16.5 Fort Ogden monitor well site Desoto County, Florida-Phase two deep exploratory drilling and monitor well construction: Brooksville, Fla., Southwest Florida Water Management District, $114 \mathrm{p}$.

Griffin, G.M., Reel, D.A., and Pratt, R.W., 1977, Heat flow in Florida oil test holes and indications of oceanic crust beneath the Southern Florida-Bahamas Platform, in Smith, D.L., and Griffin, G.M., eds., The Geothermal nature of the Floridan Plateau: Florida Bureau of Geology Special Publication, no. 21, p. 43-69.

Griffin, G.M., Tedrick, P.A, Reel, D.A., and Manker, J.P., 1969, Geothermal gradients in Florida and southern Georgia: Gulf Coast Association of Geological Societies Transactions, v. 19, p. 189-193.

Guo, W., and Langevin, C. D., 2002, User's guide to SEAWAT; a computer program for simulation of threedimensional variable-density ground-water flow and transport: U.S. Geological Survey Techniques of WaterResources Investigations, book 6, chap. A7, 77 p. 
Harrington, D., Maddox, G., and Hicks, R., 2010, Florida springs initiative monitoring network report and recognized sources of nitrate: Florida Department of Environmental Protection, $102 \mathrm{p}$.

Healy, H.G., 1975, Terraces and shorelines of Florida: Florida Geological Survey Map Series No. 71, 1:2,000,0000 scale.

Helsel, D.R., and Hirsch, R.M., 2002, Statistical methods in Water Resources: U.S. Geological Survey Techniques of Water-Resources Investigations, book 4, chap. A3, 522 p.

Hem, J.D., 1985, Study and interpretation of the chemical characteristics of natural water ( $3 \mathrm{~d}$ ed.): U.S. Geological Survey Water-Supply Paper 2254, 264 p.

Henry, H.R., and Kohout, F.A., 1972, Circulation patterns of saline groundwater affected by geothermal heatingAs related to waste disposal: American Association of Petroleum Geologists Memoir 18, p. 202-221.

Hine, A.C., 2013, Geologic history of Florida, Major events that formed the sunshine state: Gainesville, Fla., University Press of Florida, $229 \mathrm{p}$.

Hughes, J.D., Vacher, H.L., and Sanford, W.E., 2007, Threedimensional flow in the Florida platform-Theoretical analysis of Kohout convection at its type locality: Geology, v. 35 , no. 7 , p. 663-666.

Hughes, J.D., Vacher, H.L., and Sanford, W.E., 2009, Temporal response of hydraulic head, temperature, and chloride concentrations to sea-level changes, Floridan aquifer system, U.S.A.: Hydrogeology Journal, v. 17, no. 4, p. $793-815$.

Hutchinson, C.B., 1992, Assessment of hydrogeologic conditions with emphasis on water quality and wastewater injection, southwest Sarasota and West Charlotte Counties, Florida: U.S. Geological Survey Water-Supply Paper 2371, $74 \mathrm{p}$.

Johnston, R.H., Krause, R.E., Meyer, F.W., Ryder, P.D., Tibbals, C.H., and Hunn, J.D., 1980, Estimated potentiometric surface for the Tertiary limestone aquifer system, southeastern United States, prior to development: U.S. Geological Survey Open-File Report 80-406, 1 sheet.

Katz, B.G., and Bullen, T.D., 1996, The combined use of ${ }^{87} \mathrm{Sr} /{ }^{86} \mathrm{Sr}$ and carbon and water isotopes to study the hydrogeochemical interaction between groundwater and lakewater in mantled karst: Geochimica et Cosmochimica Acta, v. 60 , no. 24 , p. $5075-5087$.

Katz, B.G., Coplen, T.B., Bullen, T.D., and Davis, J.H., 1997, Use of chemical and isotopic tracers and geo-chemical modeling to characterize the interactions between ground water and surface water in mantled karst: Ground Water, v. 35, no. 6 , p. 1014-1028.
Katz, B.G., Crandall, C.A., Metz, P.A., McBride, S., and Berndt, M.P., 2007, Chemical characteristics, water sources and pathways, and age distribution of ground water in the contributing recharge area of a public-supply well near Tampa, Florida, 2002-05: U.S. Geological Survey Scientific Investigations Report 2007-5139, 83 p.

Knochenmus, L.A., 2006, Regional evaluation of the hydrogeologic framework, hydraulic properties, and chemical characteristics of the intermediate aquifer system underlying southern west-central Florida: U.S. Geological Survey Scientific Investigations Report 2006-5013, 52 p.

Kohout F.A., 1965, A hypothesis concerning cyclic flow of salt water related to geothermal heating in the Floridan aquifer: New York Academy of Science Transactions, v. 28, no. 2, p. 249-271.

Kohout, F.A., 1967, Ground-water flow and the geothermal regime of the Floridan Plateau, in Symposium on Geological History of the Gulf of Mexico Caribbean Antigen Basin: Gulf Coast Association of Geological Societies, Transactions, v. 17, p. 339-354.

Kohout, F.A., Henry, H.R., and Banks, J.E., 1977, Hydrogeology related to geothermal conditions of the Florida Plateau, in Smith, D.L., and Griffin, G.M., eds., The Geothermal nature of the Floridan Plateau: Florida Bureau of Geology Special Publication no. 21, p. 1-41.

Long, A.J., 2015, RRAWFLOW: Rainfall-Response Aquifer and Watershed Flow Model (v1.15): Geoscience Model Development, v. 8, p. 865-880, accessed August 25, 2016, at http://dx.doi.org/10.5194/gmd-8-865-2015.

Long, A.J., and Mahler, B.J., 2013, Prediction, time variance, and classification of hydraulic response to recharge in two karst aquifers: Hydrology and Earth System Sciences, v. 17, p. 281-294, accessed August 25, 2016, at http://dx.doi.org/10.5194/hess-17-281-2013.

MacNeil, F.S., 1949, Pleistocene shore lines in Florida and Georgia: U.S. Geological Survey Professional Paper 221-F, 107 p. plus plates. [Also available at http://pubs.usgs.gov/ pp/0221f/report.pdf.]

Mallams, J.L., and DeWitt, D.J., 2007, Aquifer as the fundamental unit in hydrostratigraphy and its impact on Florida nomenclature: Geological Society of America Abstracts with Programs, v. 39, no. 2, p. 88.

Marella, R.L., 2014, Water withdrawals, use, and trends in Florida, 2010: U.S. Geological Survey Scientific Investigations Report 2014-5088, 59 p. 
McDonald, H.G., 1990, Understanding the paleoecology of fossil vertebrates - Contributions of submerged sites, in Jaap, W.C., ed., Advances in underwater science: American Academy of Underwater Sciences tenth annual scientific diving symposium, St. Petersburg, Fla., Oct. 4-7, 1990, Warm Mineral Springs Archaeological Research Project.

Metz, P.A., and Lewelling, B.R., 2009, Hydrologic conditions that influence streamflow losses in a karst region of the upper Peace River, Polk County, Florida: U.S. Geological Survey Scientific Investigations Report 2009-5140, 82 p.

Miller, J.A., 1986, Hydrogeologic framework of the Floridan aquifer system in Florida, and in parts of Georgia, Alabama, and South Carolina: U.S. Geological Survey Professional Paper 1403-B, 91 p., 33 pls.

Mills, L.R., and Laughlin, C.P., 1976, Potentiometric surface of the Floridan aquifer, May 1975, and change of potentiometric surface 1969 to 1975, Southwest Florida Water Management District and adjacent areas: U.S. Geological Survey Water-Resources Investigations Report 76-80, 1 sheet.

Odum, J.K., Stephenson, W.J., Williams, R.A., Pratt, T.L., Toth, D.J., Spechler, R.M., 1999, Shallow high resolution seismic reflection imaging of karst structures within the Floridan aquifer system, northeastern Florida: Journal of Environmental and Engineering Geophysics, v. 4, no. 4, p. 251-261.

Ortiz, A.G., 2008, Potentiometric surface of the Upper Floridan aquifer, west-central Florida, May 2007: U.S. Geological Survey Open-File Report 2007-1380, 1 sheet.

Ortiz, A.G., 2011, Potentiometric surface of the Upper Floridan aquifer, west-central Florida, September 2010: U.S. Geological Survey Scientific Investigations Map 3148, 1 sheet, scale 1:500,000.

Perlman, H., 2016, Artesian water and artesian wells: The U.S. Geological Survey Water Science School, accessed August 25, 2016, at http://water.usgs.gov/edu/ gwartesian.html.

Phelps, G.G., 2001, Geochemistry and origins of mineralized waters in the Floridan aquifer system, northeastern Florida: U.S. Geological Survey Water-Resources Investigations Report 01-4112, 64 p.

Popenoe, P., Kohout, F.A., and Manheim, F.T., 1984, Seismicreflection studies of sinkholes and limestone dissolution features on the northeastern Florida shelf, in Proceedings of First Multidisciplinary Conference on Sinkholes: Orlando, Florida, October 15-17, 1984, p. 43-57.

Randazzo, A.F, 1997, The sedimentary platform of Florida, in Randazzo, A.F., and Jones, D.E., eds., The geology of Florida: Gainesville, University Press of Florida, p. 39-56.
R Core Team, 2012, R: A language and environment for statistical computing: Vienna, Austria, R Foundation for Statistical Computing, accessed August 25, 2016, at http://www.R-project.org/.

Reese, R.S., and Richardson, E., 2008, Synthesis of the hydrogeologic framework of the Floridan aquifer system and delineation of a major Avon Park permeable zone in central and southern Florida: U.S. Geological Survey Scientific Investigations Report 2007-5207, 60 p., 4 pls., plus apps. (on $\mathrm{CD}$ ).

Rosenau, J.C., Faulkner, G.L., Hendry, C.W., Jr., and Hull, R.W., 1977, Springs of Florida: Florida Department of Natural Resources, Bureau of Geology, Bulletin No. 31, $461 \mathrm{p}$.

Royal, W., and Clark, E., 1960, Natural preservation of human brain, Warm Mineral Springs, Florida: American Antiquity, v. 26 , no. 2 , p. $285-287$.

Rupert, F.R., 1994, The geology of Warm Mineral Springs, Sarasota County, Florida: Florida Geological Survey OpenFile Report 60, 7 p., accessed August 25, 2016, at http:// www.warmmineral.com/wms/wmspdf/Geology $\% 20$ of $\% 20$ WMS, $\% 20$ Sarasota $\% 20$ County $\% 20$ by $\% 20$ Frank $\% 20$ Rupert.pdf.

Ryan, J., Meaux, K., Janneman, R., and Perry, J.S., 2011, Warm Mineral Springs sampling: Sarasota, Fla., Sarasota County Environmental Services, 36 p., accessed August 25, 2016, at http://www.sarasota.wateratlas.usf.edu/upload/ documents/Warm-Mineral-Springs-Sampling-by-SarasotaCounty-Report-02-23-14-with-charts.pdf.

Ryder, P.D., 1985, Hydrology of the Floridan aquifer system in west-central Florida: U.S. Geological Survey Professional Paper 1403-F, 63 p.

Sacks, L.A., and Tihansky, A.B., 1996, Geochemical and isotopic composition of ground water, with emphasis on sources of sulfate, in the Upper Floridan aquifer and the intermediate aquifer system in southwest Florida: U.S. Geological Survey Water-Resources Investigations Report 96-4146, $67 \mathrm{p}$.

Sarasota County, 2016a, Warm Mineral Springs: Sarasota County Water Atlas, accessed August 25, 2016, at http:// www.sarasota. wateratlas.usf.edu/lake/?wbodyid $=19754 \&$ w bodyatlas=lake\#related.

Sarasota County, 2016b, Warm Mineral Springs Temperature Data for 29-April-2015 Dive: Sarasota County Water Atlas, accessed August 25, 2016, at http://www.sarasota. wateratlas.usf.edu/upload/documents/WMS-temperaturedata_4-29-2015_dive.pdf. 
Sarasota County, 2016c, Warm Mineral Springs Deep Sampling at 200-foot Vent Systems: Sarasota County Water Atlas, accessed August 25, 2016, at http://www.sarasota. wateratlas.usf.edu/upload/documents/WQ-of-WMS-VentsAthruD-29April2015-results-and-protocol.pdf.

Scott, T.M., Means, G.H., Meegan, R.P., Means, R.C., Upchurch, S., Copeland, R.E., Jones, J., Roberts, T., and Willet, A., 2004, Springs of Florida: Florida Geological Survey Bulletin. no. 66, 377 p., Chapter on Sarasota County and Warm Mineral Springs, accessed August 25, 2016, at http://publicfiles.dep.state.fl.us/FGS/WEB/springs/sarasota. pdf.

Southwest Florida Water Management District, 2016a, Water Management Information System, accessed July 5, 2016, at http://www18.swfwmd.state.fl.us/ResData/Search/ ExtDefault.aspx.

Southwest Florida Water Management District, 2016b, Water Year (October-September) Rainfall Summary Data by USGS Drainage Basin for Myakka River Basin, accessed June 10, 2015, https://www.swfwmd.state.fl.us/download/ view/site file_sets/11/surf.xlsx.

Southwest Florida Water Management District, 2016c, WestCentral Florida Water Restoration Action Plan (WRAP), accessed August 25, 2016, at https://www.swfwmd.state. fl.us/projects/wrap/.

Spechler, R.M., 1994, Saltwater intrusion and quality of water in the Floridan aquifer system, northeastern Florida: U.S. Geological Survey Water-Resources Investigations Report 92-4174, 96 p., 1 plate.

Spechler, R.M., 1996, Detection and quality of previously undetermined Floridan aquifer system discharge to the St. Johns River, Jacksonville, to Green Cove Springs, northeastern Florida: U.S. Geological Survey Water-Resources Investigations Report 95-4257, 28 p.

Spechler, R.M., and Wilson, W.L., 1997, Stratigraphy and hydrogeology of a submarine collapse sinkhole on the continental shelf, northeastern Florida, in Beck, B.F., and Stephenson, J.B., eds., The engineering geology and hydrogeology of karst terranes, Proceedings of the Sixth Multidisciplinary Conference on Sinkholes and the Engineering and Environmental Impacts of Karst, Springfield, Missouri, April 6-9, 1997, p. 61-66, accessed August 25, 2016, at http://fl.water.usgs.gov/PDF_files/ ja_spechler_red_snapper.pdf.

Sproul, C.R., 1977, Spatial distribution of ground water temperature in South Florida, in Smith, D.L., and Griffin, G.M., eds., The geothermal nature of the Floridan Plateau: Florida Bureau of Geology Special Publication, no. 21, p. 65-89.

Sproul, C.R., Boggess, D.H., and Woodard, H.J., 1972, Saline-water intrusion from deep artesian sources in the McGregor Isles area of Lee County, Florida: Florida Bureau of Geology Information Circular 75, $30 \mathrm{p}$.
Stamm, J.F., Poteet, M.F., Symstad, A.J., Musgrove, MaryLynn, Long, A.J., Mahler, B.J., and Norton, P.A., 2015, Historical and projected climate (1901-2050) and hydrologic response of karst aquifers, and species vulnerability in south-central Texas and western South Dakota: U.S. Geological Survey Scientific Investigations Report 2014-5089, 59 p., plus supplements, accessed August 25, 2016, at http://dx.doi.org/10.3133/sir20145089.

Stiff, H.A., Jr., 1951, The interpretation of chemical water analysis by means of patterns: Journal of Petroleum Technology, v. 3, p. 15-17.

Stringfield, V.T., 1966, Artesian water in Tertiary limestone in the southeastern states: U.S. Geological Survey Professional Paper 517, $226 \mathrm{p}$.

Tihansky, A.B., 2005, Effects of aquifer heterogeneity on ground-water flow and chloride concentrations in the Upper Floridan aquifer near and within an active pumping well field, west-central Florida: U.S. Geological Survey Scientific Investigations Report 2005-5268, 75 p.

Thompson, D.L., 1997, ROMP 9 Northport, Drilling and testing report, Sarasota County, Florida: Brooksville, Fla., Southwest Florida Water Management District, 231 p.

Tuttle, J.H., and Molyneaux, S.J., 1975, Sulfur bacteria from a southwestern Florida sinkhole-A preliminary report: Woods Hole, Mass., Woods Hole Oceanographic Institution, p. 12.

Upchurch, S.B., and Randazzo, A.F., 1997, Environmental geology of Florida-The geology of Florida: Gainesville, University Press of Florida, p. 217-249.

U.S. Environmental Protection Agency, 2016, Table of regulated drinking water contaminants, accessed September 2, 2106, at https://www.epa.gov/ground-water-and-drinkingwater/table-regulated-drinking-water-contaminants.

U.S. Geological Survey, 2016, Historical water-use in Florida - Counties - 1965-2010, accessed August 19, 2016, at http://fl.water.usgs.gov/infodata/wateruse/counties.html.

U.S. Geological Survey EROS Data Center, 1999, USGS NATIONAL ELEVATION DATASET (FGDC) / usgs_ned (ISO). Metadata file accessed July 6, 2016, at http://www.fgdl.org/metadataexplorer/full metadata.jsp?docId=\%7B75B1880F-EC52-4504-B56C18D814FC254C\%7D\&loggedIn=false.

Vernon, R.O., 1970, The beneficial uses of zones of high transmissivities in the Florida subsurface for water storage and waste disposal: Florida Bureau of Geology Information Circular No. 70, 39 p.

Williams, L.J., and Kuniansky, E.L., 2015, Revised hydrogeologic framework of the Floridan aquifer system in Florida and parts of Georgia, Alabama, and South Carolina: U.S. Geological Survey Professional Paper 1807, 140 p., 23 pls., accessed August 25, 2016, at http://dx.doi.org/10.3133/pp1807. 
Manuscript was approved on September 19, 2016

Prepared by the USGS Science Publishing Network Reston and Lafayette Publishing Service Centers

For more information, contact:

Director

Caribbean-Florida Water Science Center

U.S. Geological Survey

4446 Pet Lane, Suite 108

Lutz, FL 33559

http://fl.water.usgs.gov 



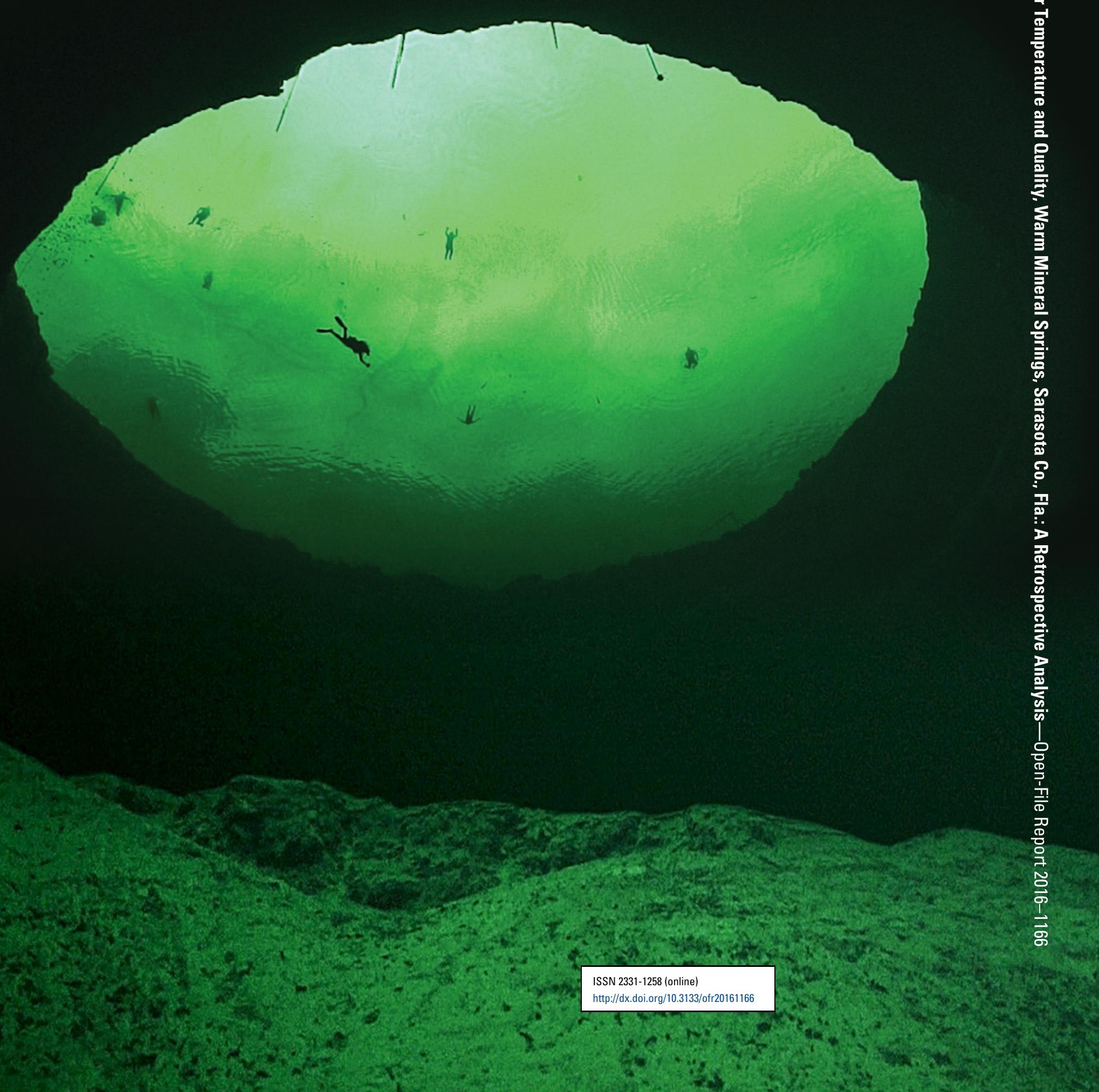

